\title{
Teaching Joint Mobilizations in Physical Therapist Assistant Programs: Implications for Instruction and Policy
}

\author{
Renae H. Gorman \\ University of St. Augustine for Health Sciences \\ DOI: https://doi.org/10.46409/sr.NJFY5485
}

Follow this and additional works at: https://soar.usa.edu/dissertations

Part of the Physical Therapy Commons, Therapeutics Commons, and the Vocational Education Commons

\section{Recommended Citation}

Gorman, R. H. (2017). Teaching Joint Mobilizations in Physical Therapist Assistant Programs:

Implications for Instruction and Policy. [Doctoral project, University of St Augustine for Health Sciences]. SOAR @ USA: Student Dissertations Collection. https://doi.org/10.46409/sr.NJFY5485

This Dissertation is brought to you for free and open access by the Student Research at SOAR @ USA. It has been accepted for inclusion in Student Dissertations by an authorized administrator of SOAR @ USA. For more information, please contact soar@usa.edu, erobinson@usa.edu. 
TEACHING JOINT MOBILIZATIONS

in

PHYSICAL THERAPIST ASSISTANT PROGRAMS:

IMPLICATIONS FOR INSTRUCTION AND POLICY

\author{
A Dissertation \\ Presented to the Faculty of the University of St. Augustine \\ in Partial Fulfillment of the Requirements for the Degree of \\ Doctor of Education
}

May 2017

by

Renae H. Gorman 


\begin{abstract}
This research answers the question: Are physical therapist assistant programs teaching the manual therapy skill of joint mobilizations? This study also gathers information regarding how the joint mobilization techniques are being instructed and assessed within the Physical Therapist Assistant programs. This information could serve as the foundation for future research regarding developing instructional and evaluation strategies for manual therapy skills. The findings of this study may also affect the physical therapist assistants in clinical performance of manual therapy. The findings are pertinent due to conflicting statements by the professional organizations and the accrediting agency of physical therapist assistant educational programs. The findings of this study identify the differing perspectives in clinical practice of manual therapy by physical therapist assistants.
\end{abstract}




\section{CHAPTER 1}

\section{Introduction}

Vocational education philosophies and conceptual frameworks focus on entry-level work tasks, pragmatism-personal fulfillment and life preparation. These frameworks are characterized by an emphasis on problem solving and higher order thinking in which learning is constructed from prior knowledge (McCaslin \& Parks, 2002; Scott \& Sarkees-Wircenski, 2008).

The majority of PTA programs are housed in two-year institutions where the Associate's Degree is the highest degree offered (CAPTE, 2017; Solon, 2013). PTA education is often viewed as aligned with a technical philosophy influenced by behaviorist and constructivist learning theories (Doolittle \& Camp, 1999; Solon, 2013). Technical education provides learning experiences that facilitate student exploration of career areas and prepare the student for employment (McCaslin \& Parks, 2002; Scott \& Sarkees-Wircenski, 2008). Behaviorism is viewed as the acquisition of skills based on environmental conditions; essentially rewarding correct behavior until the behavior is consistently demonstrated (Doolittle \& Camp, 1999; Solon, 2013). The use of performance objectives to provide the format for lesson plans, rubrics to measure task completion, and a reliance on task lists for primary source of course curriculum are examples of the application of behaviorism in education (Doolittle \& Camp, 1999). A technical education designed to provide specific pre-determined entry-level skills represents knowledge influenced by behaviorism (Doolittle \& Camp, 1999; Clark, Threeton, \& Ewing, 2010).

Constructivism is the concept that students create their own knowledge and meaning from experiences (Vygotsky, 1978; Clark, Threeton, \& Ewing, 2010). Constructivism is seen as a learning continuum that recognizes the learner's active role in the individual creation of knowledge, the influence of experiences within this process, and the realization that knowledge 
created will vary based on the experiences had (Bockarie, 2002; Clark, Threeton, \& Ewing, 2010). Furthermore, learning is seen as a lifelong process where the knowledge base and skills are continuously evolving as the environment and demands change (Bockarie, 2002). An example of the application of constructivism in PTA education would be the clinical experiences that each student participates in as a component of the curriculum. What has been valued in the classroom and laboratory setting evolves into what is important to the clinical instructor and best applied within the practice setting.

The physical therapist assistant (PTA) is the only care extender capable of providing skilled Physical Therapy. In the current healthcare environment where cost containment, productivity and providing quality care are crucial, the correct utilization of the PTA is important (Plack et al, 2006). The disparity that occurs in the utilization of the PTA is a result of the application of PTA education as well as the variability in State practice Acts (APTA, 2011). According to the American Physical Therapy Association (APTA), PTAs are not qualified to perform the manual therapy intervention of spinal or peripheral joint mobilizations (APTA, 2013). The APTA's position statement on clinical interventions that should be performed exclusively by the physical therapist includes sharp wound debridement and joint mobilizations for the spine and periphery. This position was adopted due to the high level of anatomy, assessment and constant evaluation that needs to occur simultaneously with the intervention. It was concluded that the depth of knowledge of anatomy, clinical complexity and sophistication of judgment precludes delegation to the PTA (APTA, 2013).

The position statement of interventions that should be performed exclusively by the physical therapist is one that sparks heated debates among PTs, PTAs, and PT/PTA educators (APTA, 2013; Lonneman, 2013). One of the areas of contention involves the varying opinions 
among the organizations that make decisions regarding the Physical Therapy profession and the governing bodies that license PTs and PTAs. The position of the APTA clearly states the PT is the only physical therapy provider qualified to perform spinal and peripheral mobilizations or manipulations (APTA, 2013). The APTA statement is supported by the APTA Educational Resource Paper (2013) on the appropriate delegation of mobilization and manipulation and examines the issue further by looking at the legal and liability components. It suggests that if a PTA performs mobilization procedures in States where permitted, regardless of the perspective of the relevant legal framework, the supervising PT would put him- or herself at risk of a professional liability claim (APTA, 2013). State Practice Acts, or other jurisdictional regulations may, or may not, be influenced by the APTA's core documents directly. Many practice acts have used the Model Practice Act developed by the Federation of State Boards for Physical Therapy for a framework, which does include some APTA practice language (FSBPT, 2011).

The FSBPT was created in 1987 to be an organization, separate from the APTA, to consider the "recipient" of care first. FSBPT focuses on the promotion of safe and competent physical therapy care and serves as a resource for state licensing boards (FSBPT, 2012). With its creation, FSBPT became the entity that took ownership of the National Licensure Examination for PTs and PTAs from APTA. As of 1993, FSBPT, with the assistance of expert groups identified within the organization, was responsible for the development and administration of the PT and PTA licensure exam. The PTA Task Force, consisting of licensing board members and professionals, assists in the development of the practice analysis surveys and finalizing the test content outlines once the data has been analyzed (HumRRO, 2011). In addition to this, FSBPT developed the Model Practice Act in 1996 with the intention to provide uniform standards and 
language for jurisdictions to update rules and regulations reflective of the fundamentals within the APTA core documents (FSBPT, 2012).

Membership within the APTA organization is not mandatory for practice. As a result, clinicians who are not members of the APTA may feel they do not need to comply with APTA policies, or are ambivalent to APTA perspectives; while members may not necessarily be in complete agreement with the statement. However, therapists should be aware that even if the APTA documents are stricter than the State Practice Acts or Federation recommendations; the position of the APTA as the professional organization is likely to be considered when making legal decisions (APTA, 2013). The APTA suggests that delegating joint mobilizations in direct contradiction to APTA's position places the supervising PT at an increased risk of liability (APTA, 2013). The APTA further implies that practicing outside of this position could place the profession at risk of losing the manipulation skill from its scope of practice (APTA, 2013). Ultimately, the APTA Core documents provide guidance on best Physical Therapy practice. The Federation of State Board of Physical Therapy (FSBPT) practice analysis survey of 2006 acknowledged that there was a rise in the frequency in which PTAs were performing joint mobilizations in practice (Berry \& McKnight, 2012). This information was presented to the APTA at the House of Delegates in 2006 and 2007 in an attempt to rescind the statement regarding the interventions performed exclusively by a PT (Berry, 2010). However, the motion was withdrawn and not discussed during this policy making meeting. Furthermore, in 2006 FSBPT did not conclude there was a need for the licensure examination content to change (Berry \& McKnight 2012; Hayhurst 2012; APTA, 2013). When this survey was repeated in 2010 and the findings released in 2011, the perspective changed (HumRRO, 2011; Berry \& McKnight 2012; Hayhurst 2012; APTA, 2013). In the more recent survey, items regarding the performance 
of peripheral and spinal mobilization/manipulation met the critical threshold level. From these findings, the PTA Task Force, along with the FSBPT, determined these interventions were occurring frequently enough in the clinic that there needed to be content represented on the national licensure examination despite being in direct conflict with APTA policy documents (HumRRO, 2011; APTA, 2014). In addition to including this content on the exam, the PTA Task Force determined that the ability to assess spinal and peripheral joint mobility along with performing non-thrust mobilizations of the spine and periphery are critical work activities for the PTA.

Physical Therapy and PTA Programs are accredited by an independent, national agency, The Commission on Accreditation in Physical Therapy Education (CAPTE) (CAPTE, 2017). Prior to the release of the 2011 findings, CAPTE would cite programs negatively for including joint mobilization content in the curriculum (Berry \& McKnight 2012; Hayhurst 2012; APTA, 2013). However, after the findings from FSBPT were released, CAPTE modified its perspective and ceased penalizing programs for including it in the curriculum (Berry \& McKnight 2012; Hayhurst 2012). CAPTE recognizes that the entry-level PTA should be able to demonstrate knowledge in the rationale for manual therapy procedures, including soft tissue mobilization and low amplitude joint mobilization techniques (Berry \& McKnight 2012; Hayhurst 2012; Lonnemann, 2013). CAPTE goes further to say it does not agree with the inclusion of more complex joint mobilization procedures within the educational objectives of the PTA curriculum (Berry \& McKnight 2012, CAPTE 2013).

In the FSBPT Forum Magazine article by Berry \& McKnight in 2012, there were five states recognized for taking the "absolutely not" position and another seven who are on the side of "yes" regarding the PTA and joint mobilizations. At least one of the states included in the 
category of "yes" does not actually include specific language within the Practice Act that clearly defends this stance. The "Yes" position of Massachusetts is reflected on the website of the State Licensing Board (Commonwealth of MA, 2017). According to a PT who has served as the state's chief delegate to the APTA House of Delegates, Massachusetts' Practice Act intentionally remains vague in order to prevent having language that would read as direct opposition to the APTA (J. Baldwin, personal communication February 4, 2017). This ambiguity allows the State licensing board to determine what is appropriate for practice and make adaptations readily as contemporary practice evolves (Adrian, 2010; APTA, 2015). Among care providers the ambiguity perpetuates confusion around the issue of joint mobilization and the PTA.

The conflict between the APTA, FSBPT and CAPTE, and the State practice acts can lead to the inappropriate delegation to the PTA for the application of joint mobilizations. The APTA has supportive documentation regarding interventions that are to be performed exclusively by the physical therapist (APTA, 2013). This documentation excludes all joint mobilization techniques from an assistant's practice. FSBPT licensure examination content includes peripheral joint mobilizations from grades I to IV. Documentation generated by CAPTE states that grades I and II do not require the "constant evaluation" skills of a physical therapist and can, therefore, be taught in PTA programs. However, there are no CAPTE evaluative criteria requirements regarding joint mobilizations as there are in PT education programs (CAPTE, 2013). These discrepancies perpetuate the confusion in the appropriate utilization of a PTA in joint mobilizations and are not consistent with expectations of clinical practice.

\section{Statement of the Problem}

The 2010 CAPTE clinician practice survey indicated that at least $25 \%$ of the 925 entrylevel PTA respondents regularly perform peripheral and/or spinal mobilizations (Berry \& 
McKnight 2012; Hayhurst 2012; APTA, 2013). As a result of this finding, CAPTE decided new graduates' knowledge of the rationale for the use of mobilizations should be assessed on the national licensure examination (Berry \& McKnight 2012; Hayhurst 2012; APTA, 2013). Manual therapy has been shown to be effective in treating commonly seen musculoskeletal diagnoses such as knee osteoarthritis and adhesive capsulitis of the shoulder (Deyle, Henderson, Matekel, Ryder, Garber, \& Allison, 2000; Deyle, Alison, Matekel, Ryder, Stang, Gohdes, Hutton, Henderson, \& Garber, 2005; Jansen, Viechtbauer, Lenssen, Hendriks, \& de Bie, 2011; Yang, Chang, Chen, Wang, \& Lin 2007; Kuwiboonsilp, Sakulsriprassert, Pichaiyongwongdee, Adisaiphaopan, \& Mingsoongnern, 2015; Courtney, Steffen, Fernandez de Las Peñas, Kim, \& Chmell 2016). In the most recent FSBPT practice analysis survey, joint mobilizations are an intervention that PTAs are performing in the clinic; because of this, the concepts of joint mobilizations are now included on the FSBPT national licensure exam for assistants (Berry \& McKnight, 2012). At present, it is not required for PTA programs to include joint mobilization in the program curriculum because of the position statement from the APTA. Programs may rely on clinical instructors to introduce joint mobilizations to students. Once licensed, new PTA graduates may seek continuing education opportunities to enhance these skills where joint mobilization practice is allowed.

\section{Purpose of this Study}

The purpose of this study was to determine if PTA programs have included, or are including, joint mobilizations into their curriculum; and if so, how it is being taught, and how learning is being assessed. This study is important for the identification of joint mobilization education of the PTA. This study provides a foundation for future research examining the 
utilization of the PTA in providing joint mobilization. Therefore, the entry-level education of the PTA may need to include an opportunity to learn peripheral joint mobilizations.

\section{Research Questions}

\section{Primary Research Question}

Are PTA programs including joint mobilization techniques into the curriculum? If so, what joint mobilization techniques are included?

\section{Secondary Research Question}

What instructional methods are PTA programs utilizing to teach joint mobilization techniques?

\section{Tertiary Research Question}

How is the learning of joint mobilizations assessed within the PTA coursework?

\section{Significance of this Study}

This study is significant to the PT profession because it provides details about the nature of what, and how PTA education programs are teaching for the skill of joint mobilization. This knowledge will provide a foundation for future research regarding specific teaching and assessment strategies employed by PTA programs and it may provide some context for policy development within the professional organization, the APTA.

\section{Definition of Terms}

Manual Therapy:

"Skilled... movements of joints and soft tissue, that are intended to improve tissue extensibility; increase range of motion; induce relaxation; mobilize or manipulate soft tissue and joints; modulate pain; and reduce soft tissue swelling, inflammation or restrictions" (APTA, 2015, Manual Therapy Interventions section, para 1). 


\section{Mobilization/Manipulation:}

"A manual therapy technique comprised of a continuum of skilled passive movements that are applied at varying speeds and amplitudes" (APTA, 2013 p. 2). Traditionally, manipulation is considered to be the small amplitude/high velocity technique that occurs within or at the end range of motion (APTA, 2013).

\section{Assumptions}

An assumption of this study is that the individuals completing the survey were, in actuality, the faculty members primarily responsible for teaching the joint mobilization content within their PTA programs. Another assumption is the respondents completed the survey truthfully.

\section{Limitations}

A limitation of this study is that the validity and reliability of the survey were not assessed prior to being distributed to participants. This survey was the first one of its kind developed by the principle investigator and this could also be perceived as a limitation to the study. The principle investigator received feedback from faculty regarding the questions included on the survey that may have enhanced the survey's face validity. A third limitation is the principle investigator was a novice user of the Qualtrics ${ }^{\circledR}$ Research Platform.

\section{Organization of the Remainder of the Study}

The remainder of the study consists of chapters two through five. Chapter two includes the literature review on the following topics: manipulation and mobilization education within Chiropractic and PT education, the use of manual therapy in PT clinical practice and, finally, the influence of the APTA and State practice acts in the utilization of the PTA regarding joint mobilization techniques. Chapter three explains the methodology of the study including subject 
recruitment, instrumentation development, data collection, and the Institutional Review Board (IRB) process. Chapter four encompasses data analysis and results of the research with focus on the research questions introduced in chapter one. This study concludes with a discussion of results and future recommendations in chapter five. 


\section{Chapter II-LITERATURE REVIEW}

The Guide to Physical Therapist Practice 3.0 (2015), defines manual therapy techniques as: "skilled... movements of joints and soft tissue, that are intended to improve tissue extensibility; increase range of motion; induce relaxation; mobilize or manipulate soft tissue and joints; modulate pain; and reduce soft tissue swelling, inflammation or restrictions.” Manual therapy techniques are selected by the PT when impairments related to the above outcomes are assessed in the patient examination. Peripheral joint mobilizations are included in this intervention category. The Guide 3.0 (2015) also defines mobilization/manipulation as: “(a) technique comprising a continuum of skilled passive movements to the joints and/or related soft tissue that are applied at varying speeds and amplitudes, including a small-amplitude/highvelocity therapeutic movement."

Manipulation education is a component of the accreditation criteria for physical therapist degree programs (CAPTE, 2014). In the Manipulation Education Manual for Physical Therapist Professional Degree Programs (2004), the terms “mobilization" and "manipulation” were used interchangeably but are typically very distinct in practice with mobilization including techniques performed at the grade I-IV level and manipulation only referring to a grade $\mathrm{V}$ maneuver (Manipulation Education Committee, 2004). The white paper Physical Therapists and Direction of Mobilization/Manipulation released by the APTA Public Policy, Practice and Professional Affairs Unit in 2013, established the use of the terminology of "thrust" and "nonthrust" manipulation instead of "mobilization" and "manipulation" with the intent to achieve a more common language that clearly represents the skill being performed. This white paper also highlighted the position statement that resulted from discussions at the 1999 and 2000 APTA House of Delegates (HOD P06-00-30-36). This position statement included spinal and peripheral 
joint mobilization/manipulation components of manual therapy into the category of interventions that are to only be performed by the physical therapist; not support personnel.

The utilization of thrust joint manipulation in clinical physical therapy practice has gradually increased over the past several decades (Boissonnault \& Bryan, 2005; Jette \& Delitto, 1997). However, it has been recognized in PT education research that the opportunities to practice "thrust" joint manipulation by students is limited (Struessel, et al 2012; Sharma \& Sabus, 2012). This can be attributed to the lack of qualified clinical instructors practicing the skill themselves. Therefore, clinical education may not provide the opportunity for PT students to practice (Struessel, et al 2012; Sharma \& Sabus, 2012). In addition, if the clinical instructor is not proficient with the technique, the student is less likely to apply the manipulation, even in instances when it would be appropriately indicated and the student possesses the didactic knowledge required for utilization of the technique (Sharma \& Sabus, 2012).

The research describing how the skill of performing joint mobilization is taught can be found in Physical Therapy and Chiropractic education journals. There is consensus between the PT and Chiropractic research that the traditional methods to teach mobilizations include: learning the theoretical aspects, demonstration and student practice (Descarreaux, Dugas, Lalanne, Vincelette, \& Normand, 2006). The studies have focused on teaching and learning the skills related to performing spinal mobilizations (Triano, Rogers, Combs, Potts, \& Sorrels 2002; Scaringe, Chen, \& Ross, 2000; Triano, Rogers, Combs, Potts, \& Sorrels 2003). These studies found students were able to learn complex motor skills (mobilization/manipulation) when the motor learning principles of practice and guided feedback were applied (Lee, Moseley, \& Refshauge 1990; Keating, Matyas, \& Bach, 1993; Lee, Swanson, \& Hall, 1991; Winstein, 1991; Wulf, Shea, \& Matschiner 1998; Watson \& Radwan 2001 Triano et al 2002; Triano et al 2003; 
Scaringe et al 2002; Descarreaux et al 2006; Pringle, 2004, Triano et al 2006 Cuesta-Vargas González-Sánchez, \& Lenfant, 2015). The development of innovative teaching techniques incorporating these principles while acquiring mobilization skills is also an area that is being researched in Physical Therapy and Chiropractic literature (Gonzalez-Sanchez, Ruiz-Mueoz, Avila-Bolivar, \& Cuesta-Vargas 2016; Gorgos et al 2014; Triano, McGregor, Dinulos \& Tran 2014). These studies provide a framework incorporating motor learning principles into the teaching of mobilization skills that could be applied to teaching peripheral mobilization to the PTA student. Additionally, the suggestions for future research may include, but are not limited to, simulation and the use of teaching aids (Gorgos et al 2014, Triano et al 2014).

Manual therapy has been reported to be an effective intervention frequently provided by PTs and some PTAs to improve range of motion and/or decrease pain (DiFabio, 1992). Numerous studies have demonstrated the effectiveness of these techniques when provided by a physical therapist (Nicholson, 1985; Threkheld, 1992; Vermeulen, Obermann, Burger, Kok, Rozing \& van den Ende 2000; Zemadanis, Sykaras, Athanasopoulos, \& Mandalidis 2015; Razek \& Shenouda 2014; Yang, Chang, Chen, Wang \& Lin 2007). There is currently no research regarding the PTA's ability to perform similar interventions; most likely as a direct result of the APTA position. Therefore, one cannot assume that similar results would be demonstrated when the peripheral techniques are performed by PTAs. Moreover, the research examines the effectiveness of peripheral joint mobilizations includes these specific peripheral techniques in the category of manual therapy along with other passive stretching and soft tissue mobilizations regardless of provider (Deyle et al 2000; Jansen, Viechtbauer, Lenssen, Hendriks, \& de Bie, 2011; Deyle et al 2005). 
Despite this lack of research supporting the effectiveness of the PTA performing peripheral joint mobilizations, PTAs and PTA students are reporting that they are utilizing peripheral joint mobilizations in practice. The most recent entry-level practice analysis survey results conducted by FSBPT in 2010 (findings released in 2011) found that $43 \%$ of new PTA graduates were performing peripheral joint mobilizations, $28 \%$ were performing spinal mobilizations, and $43 \%$ were performing manual traction. A survey of PTA students presented at an APTA Combined Sections Meeting in 2010, revealed 58.5\% of students were performing peripheral mobilizations and $25.9 \%$ were performing spinal mobilizations while in a clinical placement (Berry 2010, Berry \& McKnight, 2012). These findings prompted FSBPT to make some changes to the national licensure examination for PTAs in order to more accurately represent the higher minimum standard of competence that is expected in clinical practice. These changes included the addition of questions that demonstrate knowledge of non-thrust procedures (Berry \& McKnight, 2012). This decision was noted to be in direct conflict with APTA policies and positions in a curriculum gap analysis conducted by a House of Delegates appointed Task Force studying the feasibility of transitioning to an entry-level baccalaureate for the PTA degree (APTA, 2014). Continued support of this decision regarding its inclusion on the national examination is expected to be reinforced by the 2015 survey that is expected to be released in 2017.

An informal survey of PTA program directors conducted by the APTA's Director of PTA services referenced in the FSBPT Fall 2015 forum on current issues related to the PTA found that almost $82 \%$ of programs are teaching grades I and II mobilizations with $91 \%$ of these programs teaching mobilizations of the upper and lower extremity peripheral joints only. The most common reasons cited as why joint mobilizations were included in the curriculum were: 
students are expected to perform the skill during clinical experiences (72\%), employers want PTAs to possess the skill (45\%), and faculty believe that is a skill necessary to be competent in clinical practice (24\%) (J. Berry, personal communication, August 30, 2016).

Individual State practice acts also influence how the PTA performs with the supervision of a PT. According the APTA's Center for Integrity in Practice, the practice act is the law governing Physical Therapy practice within an individual state (2014). In the APTA's Board of Directors Guidelines: Defining Physical Therapy in State Practice Acts (2012), it is recommended that the definition be broad enough to include all "acts and purposes which together comprise the practice of Physical Therapy" while not being specific enough to provide an exhaustive list of every intervention. Therefore, many States have chosen not to have a direct stance on the intervention of joint mobilizations. Only seven States have specific language addressing joint mobilizations (Berry \& McKnight, 2012). This language is not always directly clear upon examination of individual practice acts. One state, Massachusetts, is included in the category of having specific language, though the language is not located within the practice act itself but on the Board of Allied Health's website under the 'Frequently Asked Questions' tab. As previously mentioned, this is because the Board has determined that peripheral joint mobilizations is a component of contemporary PT practice and should be a skill that a qualified PTA can perform. Therefore, in Massachusetts, a supervising PT can delegate peripheral joint mobilizations, despite being in direct conflict with the APTA's position. 


\section{CHAPTER 3}

\section{RESEARCH DESIGN AND METHODOLOGY}

\section{Introduction}

The APTA has a strong position against the PTA performing spine or peripheral joint mobilizations (APTA, 2000). However, the 2010 practice survey conducted by FSBPT reveals that most PTAs are regularly performing joint mobilizations in the clinic (Berry \& McKnight, 2012). As a result of this 2010 practice analysis survey, CAPTE changed the evaluative criteria of PTA programs to allow the curriculum to include rationale for limited peripheral joint mobilizations in the didactic component (Berry \& McKnight, 2012). However, the question still persists regarding how the skill is being taught and assessed within the programs.

\section{Primary Research Questions}

\section{Research Questions}

Are PTA programs including joint mobilization techniques into the curriculum? If so, what joint mobilization techniques are included?

\section{Secondary Research Question}

What instructional methods are PTA programs using to teach joint mobilization techniques?

\section{Tertiary Research Question}

How is the learning of joint mobilizations assessed within the PTA coursework?

\section{Research Design}

A survey designed by the author was sent to each PTA program listed as an accredited PTA program on the CAPTE website. An email was sent to the program director of each PTA 
program listed on the CAPTE website. The cover letter requested that only the faculty member who teaches joint mobilizations complete the survey.

\section{Description of Population and Sampling}

The population for this research is all accredited PTA programs in the United States.

\section{Study Sample}

The study sample includes faculty members who teach joint mobilizations in accredited PTA programs listed on the CAPATE website. The survey was sent to each of the 276 accredited PTA programs with 118 (42.7\%) responding.

\section{Recruitment Method}

The names of accredited PTA programs were obtained from the CAPTE website accessed on November 1, 2016. An email was sent to the director of each PTA program, explaining the purpose of the study (Appendix A), providing a link to the research survey, and serving as notice of informed consent. The email requested that the directors forward the survey to the individual who was the primary faculty member teaching joint mobilization in the PTA curriculum. All responding individuals were informed of the purpose of the study and agreed electronically to participate before answering the survey questions. Each respondent was informed that all data would be reported in aggregate and remain confidential.

\section{Ethical Considerations}

Approval to conduct research was received from the IRB committees at The University of St. Augustine for Health Sciences (USAHS) and Springfield Technical Community College (STCC). STCC provided access to the survey software, Qualtrics ${ }^{\circledR}$. The letters of IRB approval are located in Appendix B. 
Confidentiality of the participants was maintained by the surveys being accessed through an anonymous link provided by the Qualtrics ${ }^{\circledR}$ Web-Based Survey Platform. There was no personal identifying information obtained within the body of the survey that could be used to isolate which PTA program provided which survey responses. At the conclusion of the survey, respondents were asked to provide contact information only if they wanted to see the results of the study. This information could not be linked to specific results within the data analysis software.

\section{Instrumentation Development}

The survey was developed by the principle investigator (Appendix C). It was determined that the utilization of the survey approach would be the most appropriate method to gain information that answers the research questions of this study (Portney \& Watkins, 2000). The question development and sequencing was influenced by two previously published PT education research surveys to improve the survey's face validity. The first study was survey research collecting data regarding the evolution of PT education curricula to include joint mobilization as manual therapy became more widely incorporated into practice in the 1980s (Ben-Sorek \& Davis 1988). The second study identified potential student-perceived barriers to learning and practicing joint manipulation skills (Struessel, Carpenter, May, Weitzenkamp, Sampey \& Mintken, 2012).

\section{Data Collection}

Survey results were received via Qualtrics ${ }^{\circledR}$ and the data were compiled for analysis in Qualtrics $^{\circledR}$. Statistical Analyses were completed using the Reports and Analysis feature of Qualtrics ${ }^{\circledR}$. 


\section{Data Collection Procedure(s)}

Attempts to recruit participants were distributed electronically to each program director of the accredited PTA programs as found on the CAPTE website on November 1, 2016. This email explained the purpose of the investigation, goals of the research being conducted and the survey link. The survey was developed within the Qualtrics ${ }^{\circledR}$ Web-Based Survey Platform.

\section{Data Analysis}

The report generating feature of the Qualtrics ${ }^{\circledR}$ Web-Based Survey Platform was used to analyze the information obtained from the survey. The data provided relevant information regarding the joint mobilization teaching and assessment techniques employed by each of the programs.

\section{Suggestions for Future Research}

The intent of this study is to examine if PTA programs include joint mobilization in the curriculum. The results of this study suggest future directions for research aimed at the education of PTAs regarding mobilization techniques. This research could examine the effectiveness of teaching strategies or the development of new strategies, such as simulation. Future research could also examine the effectiveness and confidence of PTAs providing peripheral joint mobilizations at the entry-level This effectiveness could then be compared to expert PTA practice in future research. Understanding if PTAs are, or are not, effective in providing this intervention could further clarify the role and utilization of the PTA in joint mobilization clinical practice.

This study highlighted areas of confusion and discrepancy within the organizations that influence PTA education and the documents that support PT practice. The development of educational strategies to clarify the joint mobilization discrepancies and educate physical 
therapists about the appropriate clinical practice utilization of joint mobilizations by the PTA could also be areas of future research. 


\section{CHAPTER IV}

\section{RESULTS}

The purpose of this study was to determine if the intervention of joint mobilization is being taught in PTA programs. Further objectives of the study were to determine what type of skills are being taught, how they are taught and what other factors influence the inclusion of this skill in the PTA curriculum.

\section{Demographics}

Responses were received from 119 surveys, $43 \%$ of the sample of 276 accredited PTA programs as listed on the CAPTE website as of November 1, 2016. There were 13 emails undelivered due to incorrect or out-of-date email addresses and two surveys that were started but not completed and, therefore, not included in the data analysis. However, the analyses of the results indicated there were questions that respondents did not provide answers for and this is reflected in the appropriate tables. The demographics of the respondents are included in Table 1. The instructions requested that the instructor who is primarily responsible for teaching manual therapy techniques in the curriculum complete the survey. The majority of the respondents were PTA program directors $(68.38 \%)$ with the other respondents being Directors of Clinical Education, Full-time Faculty, or Adjunct Faculty. Over $80 \%$ of the respondents noted they were the individual responsible for teaching manual therapy in the curriculum and the remaining respondents marked themselves as not being the person responsible for the manual therapy content. The survey did not provide an opportunity for the responder to explain why the manual therapy instructor was not the one completing the survey. Only two $(0.16 \%)$ respondents indicated that joint mobilization was not included within their program's curricula. There were respondents from each region of the country with accredited PTA programs with most being 
from the Midwest region (33.90\%). Public institutions represented within the responses account for $72.03 \%$ of the responding programs.

Table 1

Demographic Characteristics of Respondents

\begin{tabular}{llll}
\hline Variable & Level & \# of Respondents & \% of Respondents \\
& & & \\
\hline Primary Role within & Program Director & 80 & 7.38 \\
PTA program & Director of Clinical Education & 9 & 6.84 \\
& Adjunct Faculty & 8 & 17.09 \\
& Other & 20 & \\
Responsible for & Yes & 99 & 83.90 \\
teaching manual & No & 19 & 16.10 \\
therapy content & & & \\
& & 20 & 16.95 \\
Region of country & Northeast & 4 & 3.39 \\
where program is & Mid-Atlantic & 28 & 23.73 \\
located & Southeast & 40 & 33.90 \\
& Midwest & 21 & 17.80 \\
& Southwest & 4 & 3.39 \\
& Northwest & 1 & 0.85 \\
& Puerto Rico & & 72.03 \\
Type of Institution & Public & 85 & 27.97 \\
& Private & 33 & \\
\hline
\end{tabular}

\section{APTA Involvement}

Over $94 \%$ of respondents noted that they are APTA members and $85.84 \%$ of this group indicated that they belong to special-interest sections. The section membership is in addition to APTA membership and provides the member with additional resources within a area of expertise specific to practice setting or interest area (APTA, 2017). A majority of respondents indicated that they belong to more than one section and a few were members of three or more sections. Thirteen of the individuals $(11 \%)$ that responded indicated that they held advanced certifications in Manual Therapy. Almost 40\% of respondents (47 programs) indicated that student APTA 
membership is required within their program. Table 2 reports these findings and Appendix D lists the specific responses regarding the section membership and advanced certifications.

A majority of all respondents $(83.48 \%$ or 96$)$ indicated that they have attended APTA sponsored conferences in the last 5 years. The most frequently noted conferences attended were: State Chapter conferences, Combined Sections Meeting (CSM), APTA National Conference and Exposition (NEXT), and Education Leadership Conference (ELC). There were 27 respondents $(23.48 \%)$ that indicated they held memberships in other professional organizations. These findings are depicted in Table 2 and the list of the other professional organization memberships in Appendix D.

Table 2

APTA Involvement and Professional Membership

\begin{tabular}{|c|c|c|c|}
\hline Question & Response & \# of Respondents & $\%$ of Respondents \\
\hline $\begin{array}{l}\text { Are you an APTA } \\
\text { Member? }\end{array}$ & $\begin{array}{l}\text { Yes } \\
\text { No }\end{array}$ & $\begin{array}{l}110 \\
7\end{array}$ & $\begin{array}{l}94.02 \\
5.98\end{array}$ \\
\hline $\begin{array}{l}\text { Do you belong to any } \\
\text { APTA sections? }\end{array}$ & $\begin{array}{l}\text { Yes } \\
\text { No }\end{array}$ & $\begin{array}{l}97 \\
16\end{array}$ & $\begin{array}{l}85.84 \\
14.16\end{array}$ \\
\hline $\begin{array}{l}\text { Does your program } \\
\text { require APTA } \\
\text { membership? }\end{array}$ & $\begin{array}{l}\text { Yes } \\
\text { No }\end{array}$ & $\begin{array}{l}47 \\
71\end{array}$ & $\begin{array}{l}39.83 \\
60.17\end{array}$ \\
\hline $\begin{array}{l}\text { Do you hold any } \\
\text { advanced } \\
\text { certifications? }\end{array}$ & $\begin{array}{l}\text { Yes } \\
\text { No }\end{array}$ & $\begin{array}{l}13 \\
104\end{array}$ & $\begin{array}{l}11.11 \\
88.89\end{array}$ \\
\hline $\begin{array}{l}\text { Have you attended } \\
\text { any APTA } \\
\text { conferences in past } 5 \\
\text { years? }\end{array}$ & $\begin{array}{l}\text { Yes } \\
\text { No }\end{array}$ & $\begin{array}{l}96 \\
19\end{array}$ & $\begin{array}{l}83.48 \\
16.52\end{array}$ \\
\hline $\begin{array}{l}\text { Other Professional } \\
\text { Organization } \\
\text { Membership }\end{array}$ & $\begin{array}{l}\text { Yes } \\
\text { No }\end{array}$ & $\begin{array}{l}27 \\
88\end{array}$ & $\begin{array}{l}23.48 \\
76.52\end{array}$ \\
\hline
\end{tabular}




\section{Patient Contact Hours}

There were three survey items (questions: six, seven and eight) utilized to determine if the respondents practiced clinically. Respondents were able to choose the range of hours that most closely represented their weekly patient contact hours. Almost 64\%, or 75 individuals, noted that they did have patient contact hours with $97 \%$ of those responses having 0-15 patient contact hours/week with the majority $(33.77 \%)$ of them practicing within a private practice setting. Table 3 depicts the responses to these questions. The practice settings that were indicated in the category of "Other" are listed in Appendix E. Those that responded that they did not have patient contact hours were asked to skip these three questions and proceed to question nine. Table 3

Patient Contact Hours and Practice Setting

\begin{tabular}{llll}
\hline Question & Response & \# of Responses & \% of Reponses \\
& & & \\
\hline $\begin{array}{l}\text { Any patient contact } \\
\text { hours? }\end{array}$ & Yes & 75 & 63.56 \\
& No & 43 & 36.44 \\
Of those that & $0-5$ & 43 & 57.33 \\
indicated patient & $6-15$ & 26 & 34.67 \\
contact hours, how & $16-24$ & 4 & 5.33 \\
many hours a week of & 25 or more & 2 & 2.67 \\
direct patient care & & & \\
& & 7 & 9.09 \\
Practice Setting & Hospital Based & & \\
& outpatient clinic & 26 & 33.77 \\
& Private practice & 7 & 9.09 \\
& Acute Care & 10 & 12.99 \\
& SNF & 12 & 15.58 \\
& Home health care & 15 & 19.48 \\
\hline
\end{tabular}


State Practice Acts

Participants were asked if they were aware of specific language existing within their state practice acts that addresses the PTA and the ability to perform joint mobilizations. Results indicated that $50 \%$ of respondents are not aware of specific language within the practice act regarding the PTA and joint mobilizations; $8.47 \%$ noted that the state practice act clearly states the PTA is not permitted to perform joint mobilizations; $27.12 \%$ indicated that the State practice act has language that permits the PTA to perform joint mobilizations, two respondents were unsure if their state's practice act has specific language and 15 noted "Other". Table 4 notes the responses that were provided as "Other".

Table 4

Responses Provided as “Other” Regarding State Practice Act Language

- Grades I, II, III, IV with supervision and instruction of PT

- School on state line between one state that allows and one that does not

- Only OK if determined by supervising PT, training and competency

- We teach grade I \& II, our practice act uses thrust manipulation language

- Up to grade IV

- [State abbreviation] practice act lumps all manual therapies together

- $\quad$ Practice act] leaves it open

- PTs and PTAs cannot perform spinal joint mobilizations

- Specifically states no spinal joint mobilization. Peripheral joints are not addressed

- We have a position statement from our state board that PTA can perform peripheral joint mobs, but not spinal mobs, as long as they have been sufficiently educated and trained in joint mobs.

- PTAs may perform with appropriate training

- PTAs are allowed to perform peripheral joint mobilizations, but no spinal mobilizations

- Not an excluded skill

- Our practice act states that the PT is able to delegate to the PTA as long as there is documented competency

- Practice act states PTAs can 


\section{Curriculum}

The respondents were asked to note what courses were required before introducing joint mobilization content to program enrollees. The two choices that were provided on the survey were an Anatomy and Physiology course and Kinesiology. There was a choice of "Other" allowing the individual to note what courses were also considered prerequisites for manual therapy. Table 5 reflects the responses provided regarding the prerequisite courses. Appendix F lists the courses that were noted under the "Other" category.

Table 5

Manual Therapy Prerequisite Courses

\begin{tabular}{lll}
\hline Prerequisite Courses & \# of Reponses & \% of Responses \\
\hline Anatomy \& Physiology & 106 & 89.83 \\
Kinesiology & 101 & 85.59 \\
Other & 40 & 33.90 \\
\hline
\end{tabular}

The programs surveyed were asked how long the content of peripheral joint mobilizations has been included in the curriculum and in which semester it is initially presented to students. This information is depicted in Table 6 . The longest time frame represented by $32 \%$ of the programs was 3-5 years. Nearly $100 \%$ of the programs surveyed include the peripheral joints in the instruction of manual therapy; and typically as a unit within a course. Table 6 demonstrates that the majority of programs introduces joint mobilization content as a sub-unit of a separate course and Appendix G lists the courses that programs indicated include joint mobilization information. Only one program teaches manual therapy as a separate course. Spine and pelvis mobilizations are included within the curriculum of $30-37 \%$ of the programs; depending on which section of the spine is being referred to. The joint mobilization content, in general, is most 
frequently introduced within the third semester of the program (37.63\% or 44 of the programs) but $11 \%$ of programs introduce joint mobilization content in the first semester.

The common manual therapy approaches that influence the content were: Paris, Cyriax, Kaltenborn, Maitland, McKenzie, and Mulligan. Table 7 lists the different approaches that influence programs' curricula and Appendix H reflects the responses written in "Other". Table 6

Inclusion of Joint Mobilization Content

\begin{tabular}{llll}
\hline Survey Question & Response & \# of Responses & \% of Responses \\
& & & 11.11 \\
\hline Where is joint & First semester & 13 & 29.91 \\
mobilization content & Second semester & 35 & 37.61 \\
first presented? & Third Semester & 44 & 19.66 \\
& Fourth semester & 23 & 1.71 \\
& Not at all & 2 & \\
& & & 0.88 \\
In what course is & Separate required & 1 & \\
joint mobilization & course & 106.46 \\
first introduced? & Sub-unit of another & & \\
& course & 109 & 24.56 \\
How long has joint & 0-2 years & 28 & 31.58 \\
mobilization content & 3-5 years & 36 & 19.30 \\
been included in & 6-10 years & 22 & 7.02 \\
your curriculum? & 11-15 years & 8 & 17.54 \\
& $>15$ years & 20 & \\
\hline
\end{tabular}

Grades I and II mobilizations are didactically taught by $98 \%$ and $99 \%$ of the programs respectively with grades III and IV included by over $80 \%$ of the programs. There were three respondents that noted "Other" when asked about which grades of mobilization were taught in the classroom. The responses that were provided with this selection were: "NAGS, SNAGs and MWMs (Mulligan)"; "We teach about other grades but only expect those listed"; and "What others?". The majority (roughly 94\%) of programs also teach the clinical application of grades I 
and II in a laboratory setting. Interestingly, two programs reported teaching grade V mobilizations in a lab for clinical application. There were nine respondents that selected "Other" for mobilization grades taught for clinical application. The responses given in the space provided were: "We introduce mobilization grades 1-3 but do not spend a lot of lab time on it due to being outside of scope of PTA practice in [state abbreviation]”; “...I demonstrate...but do not have (the students) perform the mobs"; "NAGS, SNAGs and MWMs"; "Demonstrate I-IV but only test on grades I-II"; "no required lab"; and four responses were "None".

The primary means of teaching the joint mobilization content were demonstration (93.80\%) and lecture (90.27\%). There were ten respondents that indicated "Other", but do to an error in the survey settings, some of the responses here were most likely a result of being unable to select multiple choices. These strategies that were not included in the list provided were: laboratory practice on peers, competency check offs, team-based learning, and clinic hours. One program responded that outside clinicians come in and do a hands-on lab experience for students. However, during the initial phase of data collection, the formatting of this question had an error in not allowing respondents select more than one response even though the question suggested marking more than one. The first four comments for this question suggested respondents wanted to select more than one choice. This feature was rectified within the first 36 hours of the survey being live and the additional selections given in the comments were factored into the final results that are reflected in Table 7.

Programs were also asked to note how many total hours were allotted to teaching joint mobilizations using all of the teaching methods that were utilized. The majority of the responses $(75.22 \%)$ indicated the total number of teaching hours were within 2.5 hours to 10 hours with the most frequent response falling within the "4.5-6 hours" category. There were 22 responses that 
indicated they utilized more than 10 hours to teach joint mobilizations, with two of these responses indicating more than 30 hours. Responses are depicted in Table 7.

The selections given to study participants when asked about assessment strategies were: written examination, practical examination, both or other. Several programs report using a combination of practical and written examination to assess the learning of joint mobilizations (49.55\%). The assessments that were included in "Other" were: "none", and competency or skills check-offs (different than practical examination and sometimes used in conjunction with a written exam).

Table 7

Curriculum Information

\begin{tabular}{llll}
\hline Survey Question & Response Choices & \# of Responses & \% of Responses \\
& & & \\
\hline Which techniques & Paris & 25 & 23.58 \\
are emphasized? & Cyriax & 23 & 21.70 \\
& Kaltenborn & 32 & 30.19 \\
& Maitland & 71 & 66.98 \\
& Other & 51 & 48.11 \\
What body regions & Pelvic and/or Sacroiliac & 40 & 34.19 \\
are included? & Joints & & \\
& Lumbar Spine & 43 & 36.75 \\
& Thoracic Spine & 36 & 30.77 \\
& Cervical Spine & 39 & 33.33 \\
& Upper Extremity & 115 & 98.29 \\
& Lower Extremity & 116 & 99.15 \\
What mobilization & I & & \\
grades are taught & II & 110 & 98.21 \\
didactically? & III & 111 & 99.11 \\
& IV & 99 & 88.39 \\
& V & 90 & 80.36 \\
& Other & 48 & 42.86 \\
Whades are taught in & II & 3 & 2.68 \\
& III & 107 & 94.69 \\
\hline & & 106 & 93.81 \\
& & 46 & 40.71 \\
\hline
\end{tabular}




\begin{tabular}{llll}
\hline a lab for clinical & IV & 30 & 26.55 \\
application? & V & 2 & 1.77 \\
& Other & 9 & 7.96 \\
Teaching methods & Demonstration & 106 & 93.80 \\
used? & Lecture & 102 & 90.27 \\
& Video & 54 & 47.79 \\
& Simulation Lab & 64 & 56.64 \\
& Required Reading & 64 & 56.64 \\
& Other & 9 & 7.96 \\
Total hours allotted & $0-2$ & & \\
to teaching joint & $2.5-4$ & 6 & 5.31 \\
mobs & $4.5-6$ & 27 & 23.89 \\
& $6.5-10$ & 30 & 26.55 \\
& $>10$ & 28 & 24.78 \\
Learning & & 22 & 19.47 \\
assessments & Written & 3 & \\
& Practical & 40 & 2.70 \\
& Both & 55 & 36.04 \\
& Other & 13 & 49.55 \\
\hline
\end{tabular}

Note: These questions allowed participants to select more than one response

\section{Clinical Education Partner Information}

Of the PTA programs that responded to the clinical education partner questions, 85 $(62.11 \%)$ report that the majority of their clinical partners (sites where the programs frequently place PTA students for clinical education) utilize joint mobilizations in their practice. The programs were also asked if clinical education partners expect PTA students to demonstrate competence in joint mobilizations by the time the students are placed for their clinical education. A majority of programs (64 or $57.14 \%$ ) reported that joint mobilization competence is an expectation of clinical education partners, however, the data collected does not permit reporting on if this is the case despite the State's practice act language. Identifiers were removed from the analysis and, therefore, makes it unclear if the clinical partners that expect students to demonstrate knowledge of this skill are located within states where it is prohibited by the State Practice Act. The results of the clinical education survey questions are reflected in Table 8. 
Table 8

Clinical Education Partner Information

\begin{tabular}{llll}
\hline Survey Question & Response Choices & \# of Respondents & \% of Responses \\
\hline Percentage of clinical & $0-20 \%$ & 2 & 2.11 \\
partners that utilize & $21-40 \%$ & 8 & 8.42 \\
joint mobilizations in & $41-60 \%$ & 26 & 27.37 \\
practice & $61-80 \%$ & 30 & 31.58 \\
& $81-100 \%$ & 29 & 30.53 \\
& & 64 & 57.14 \\
$\begin{array}{l}\text { Is competence of } \\
\text { joint mobilizations an }\end{array}$ & Yes & 48 & 42.86 \\
$\begin{array}{l}\text { expectation of } \\
\text { clinical partners? }\end{array}$ & & \\
\hline
\end{tabular}

\section{Professional Beliefs}

The survey concluded with four questions that asked program representatives to respond with an answer that was most closely in alignment with the responder's own professional beliefs. Table 9 reflects the responses to these questions. A majority of programs (56.41\%) responded "Strongly Agree" or "Agree" with the statement that their program adequately prepares their PTA students to perform peripheral joint mobilizations during their clinical experiences. Additionally, 75\% of the respondents noted a "Strongly Agree" or "Agree" response indicating that peripheral joint mobilizations should be an entry-level skill for the PTA. Almost $72 \%$ of the participants responded that they do not believe spinal mobilizations should be an entry-level skill for the PTA. Finally, over 91\% of the responses indicated that they "Strongly Agree" or "Agree" that the language regarding the PTA and joint mobilization in documents from the APTA should be in more alignment with the findings from CAPTE and FSBPT in order to support the PTA to provide the manual therapy skill of peripheral joint mobilizations. 
Table 9

Professional Beliefs

\begin{tabular}{|c|c|c|c|}
\hline Statements & Response Choices & \# of Responses & $\%$ of Responses \\
\hline $\begin{array}{l}\text { Students are } \\
\text { adequately prepared } \\
\text { to perform joint } \\
\text { mobilizations }\end{array}$ & $\begin{array}{l}\text { Strongly Agree } \\
\text { Agree } \\
\text { Neither agree nor } \\
\text { disagree } \\
\text { Disagree } \\
\text { Strongly disagree }\end{array}$ & $\begin{array}{l}21 \\
45 \\
16 \\
\\
28 \\
7\end{array}$ & $\begin{array}{l}17.95 \\
38.46 \\
13.68 \\
\\
23.93 \\
5.98\end{array}$ \\
\hline $\begin{array}{l}\text { Peripheral joint } \\
\text { mobilizations should } \\
\text { be an entry-level } \\
\text { PTA skill }\end{array}$ & $\begin{array}{l}\text { Strongly Agree } \\
\text { Agree } \\
\text { Neither agree nor } \\
\text { disagree } \\
\text { Disagree } \\
\text { Strongly disagree }\end{array}$ & $\begin{array}{l}49 \\
38 \\
13 \\
12 \\
4\end{array}$ & $\begin{array}{l}42.24 \\
32.76 \\
11.21 \\
10.34 \\
3.45\end{array}$ \\
\hline $\begin{array}{l}\text { Spinal mobilizations } \\
\text { should be an entry- } \\
\text { level PTA skill }\end{array}$ & $\begin{array}{l}\text { Strongly Agree } \\
\text { Agree } \\
\text { Neither agree nor } \\
\text { disagree } \\
\text { Disagree } \\
\text { Strongly disagree }\end{array}$ & $\begin{array}{l}7 \\
13 \\
13 \\
46 \\
37\end{array}$ & $\begin{array}{l}6.03 \\
11.21 \\
11.21 \\
39.66 \\
31.90\end{array}$ \\
\hline $\begin{array}{l}\text { The language in } \\
\text { APTA documents } \\
\text { should be in more } \\
\text { alignment with } \\
\text { findings from } \\
\text { CAPTE and FSBPT }\end{array}$ & $\begin{array}{l}\text { Strongly Agree } \\
\text { Agree } \\
\text { Neither agree nor } \\
\text { disagree } \\
\text { Disagree } \\
\text { Strongly disagree }\end{array}$ & $\begin{array}{l}73 \\
31 \\
3\end{array}$ & $\begin{array}{l}64.04 \\
27.19 \\
2.63 \\
\\
2.63 \\
3.51 \\
\end{array}$ \\
\hline
\end{tabular}

Survey Closing Remarks

The final question of the survey asked respondents to provide the researcher with any suggestions or comments that might be relevant to the study. Twenty-five participants provided responses that could be categorized into the following themes: suggestions for future research; modifications to the current survey: question formatting or content; frustrations with program requirements or timeline limitations; the need to educate PTAs for the licensing examination and 
clinical practice; the influence of State regulation language on the inclusion of joint mobilizations into the curriculum, and finally, recognizing the disconnect between current practice and the various organizations. The specific comments in response to the final request can be found in Appendix I. 


\section{CHAPTER V}

\section{SUMMARY and DISCUSSION}

The results of this study support the influence of the behaviorist and contructivism learning theories within the PTA curriculum. The PTA curricular framework influenced by these theories provides the learner with opportunities to gain knowledge in the classroom and develop the skills necessary for clinical practice. The purpose of this study was to determine if PTA programs include peripheral joint mobilizations in the curriculum, and if so, how it is being taught, and how PTA student learning is assessed. This study is significant to the profession because it provides a foundation of what responding PTA education programs are doing to teach the skill of joint mobilization. It is well established that manual therapy is an integral component of physical therapy. Manual therapy has been demonstrated to be an effective modality for increasing range of motion and decreasing pain for patients with these impairments secondary to a variety of diagnoses like osteoarthritis or adhesive capsulitis (Deyle 2000, Deyle 2005, Yang 2007, Jansen 2011, Kuwiboonsilp 2015, \& Courtney 2016). The profession of PT is striving to be an evidence-based practice and, therefore, the curriculum should include the interventions that have been demonstrated to be effective in the evidence. Given the importance of this intervention in the physical therapy profession and to practicing PTs and PTAs this study provides the clarification needed about the PTA joint mobilization education.

The responses to the survey were provided by PTA program directors who also reported that they were the individuals responsible for teaching manual therapy content. In addition, several of the respondents noted that they also maintained additional professional certifications relative to manual therapy or orthopedics. This supports the idea that the instructor has the contextual knowledge of joint mobilizations and, thus, leads the development of the students' knowledge and learning experiences; which aligns with constructivism (Bockarie, 2002). 
There was a wide range of geographic areas represented in the survey results enabling generalizability in the interpretation of the findings. However, a limitation of the study was not having the respondents indicate which state they were from; instead states were grouped together by region. This was a direct intent of the researcher in order to protect program identity but it also limits the deeper understanding of the findings. Another layer of analysis that could have been added would have been to see if responses regarding why certain content was included or not included in the curriculum was a direct result of State level legislative regulation.

A majority of survey participants were members of the APTA, belonged to special interest sections and had attended professional conferences within the past five years. This is a finding of relevance because APTA members, and especially members involved in PTA education, should be aware of the APTA's stance on the PTA's ability to perform joint mobilizations in clinical practice. The affirmative responses to the survey questions specifically referencing the inclusion of joint mobilizations in the curriculum are in direct opposition to the APTA perspective; despite the inclusion of joint mobilizations in the curriculum is permitted by CAPTE. This finding begs the question about why these educators, who are members and acting in opposition to the APTA stance, are not more active in changing the positon of the APTA.

Participants were asked to indicate if they have clinical patient contact hours and in what type of setting. This was a relevant question to ask because a survey of PT faculty regarding the inclusion of joint manipulation in PT curriculum, $87 \%$ of faculty that believed joint manipulation should be included in the professional program also work in the clinic (Boissonnault, Bryan \& Fox, 2004). This current research is looking at the PTA education, thus, knowing if the PTA faculty surveyed are active in contemporary practice was important to the researcher. The researcher of this current study is aware that joint mobilization and manipulation are two distinct 
skills, however, still believed knowing if the educator works in a setting where the manual therapy was provided would be valuable information. If the educator is also a provider of joint mobilizations, and therefore, values joint mobilizations as an effective treatment modality; this would then be similar to how the PT faculty involved in clinical practice see the value of including joint manipulation in the PT curriculum. Another level of questioning that could have been examined further here would have been if the respondent utilizes manual therapy, specifically joint mobilizations, in his or her own practice. This information could have enriched the results regarding the educator's perception on the value of manual therapy. The practice setting where several respondents see patients was the outpatient setting (either hospital based or private practice) where manual therapy is a frequent intervention provided to clients (Sharma \& Sabus, 2012). However, the impact of personal practice patterns by respondents was not elucidated.

A troubling finding in this survey was that over $50 \%$ of respondents were not aware of, or were unsure about, specific language within their practice acts about the PTA utilizing joint mobilizations. This negative response could have been a result of the question not using more generic language when referring to a "Practice Act". There are States that do not have a "Practice Act" but that do have other legislative or jurisdictional documents that regulate Physical Therapy practice in that state. These documents may be titled "Administrative Rules", "Municipal Regulations", "Statutes", or "Annotated Code" and therefore, respondents who reside in states with these alternative documents, may not have been familiar with the terminology of "Practice Act". However, if that is not the case, this $50 \%$ response indicates that half of the PTA faculty responding to the survey are not familiar with their State Practice Act. This lack of familiarity with State practice regulations is disheartening. A misunderstanding of the statutes could lead to 
disciplinary action. Potential violations that are punishable by the regulatory agencies are: practicing beyond the scope of practice and violation of statutes, regulations or laws (Chaudry, 2014; FSBPT, 2017; Mohr, Ingram, Mabey \& Walker, 2014) In a ten-year history of PTA disciplinary reports, failure to comply with statutory requirements represented over $10 \%$ of the complaints brought against 1139 PTAs. (Mohr, Ingram, Mabey \& Walker, 2014). These examples of disciplinary reports are not necessarily related to mobilizations; those specifics were not reflected in the report. Therefore, the assumption that the disciplinary actions were related to how manual therapy was applied in practice cannot be made.

There were no surprises that the most frequently reported prerequisite courses necessary before manual therapy and joint mobilizations are introduced in the PTA curriculum were Anatomy \& Physiology and Kinesiology. These courses provide the scaffolding necessary to introduce the concepts that the skill of joint mobilization is developed from. This idea of scaffolding is developed from constructivism (Bockarie, 2002). The learning process moves from passive to active (classroom to lab then on to clinic) and the instructor guides the student's development (Bockarie, 2002).

Manual therapy is most commonly included as a sub-unit of another course. This finding aligns with previous surveys of PT programs and that they traditionally include joint mobilizations within other courses within their curriculum (Boissonnault, Bryan \& Fox, 2004). Physical therapy programs typically offer separate spine and extremity courses that permit the faculty to have more time to discuss manual interventions. CAPTE requires graduates of accredited PTA programs complete the curriculum within five semesters. This constraint limits the ability of programs to provide additional courses to expand upon interventions beyond the Minimum Required Skills of the PTA at Entry-Level (APTA, 2012). 
This Minimum Skills document outlines the skills that have been deemed to be "foundational" and "indispensable" for a new PTA graduate. The document provides a "taskoriented" list for the entry-level PTA which is in alignment with the behaviorism approach to education (Doolittle \& Camp, 1999). Joint mobilizations are not included under manual therapy as one of the skills required. The results of the 2010 practice analysis survey of entry-level (less than 3 years since initial licensure) PTAs showed that $25 \%$ of these clinicians are performing spine and peripheral non-thrust joint mobilizations (HumRRO, 2011). As a result, FSBPT's PTA Task Force determined that the ability to perform the interventions related to mobilization of the spinal and periphery are critical work activities for the PTA (HumRRO, 2011). This is evidence of why the practice analysis is important; to ensure that the licensing exam content reflects what is expected and performed in the clinic. The findings of the FSBPT PTA Task Force research may support the addition of peripheral joint mobilizations to the Minimum Required Skills of the PTA at Entry-Level.

Programs were also asked questions regarding the manual therapy and joint mobilization content included in the PTA curriculum. There was no agreement on the techniques emphasized. This finding is supported within the CAPTE aggregate program data document that $45.04 \%$ of PTA programs use a "traditional" curricular model and an additional $42.21 \%$ of PTA programs use a "hybrid" model (CAPTE, 2017). The "traditional" model begins with basic science, then followed by clinical science and then physical therapy science. A "hybrid" curricular model is a combination of traditional, problem-based, case-based and guide-based. This question allowed the respondents to select more than one choice and each technique was selected several times. It was surprising to see that several programs included the regions of the spine in their curriculum despite the anecdotal controversy that exists around the PTA performing spinal mobilizations. 
The risk of serious injury following manipulation of the cervical or lumbar regions has been shown to be small in published literature reviews (Di Fabio, 1999; Flynn, 2002). In addition, there is literature to show manipulations do not have better outcomes than non-thrust mobilization techniques (DiFabio, 1999; Kaur, Sharma, Singh \& Singh 2014). The 2010 FSBPT practice analysis survey supports the inclusion of spinal mobilizations in the PTA curriculum but the educators surveyed agreed this skill is not appropriate to delegate to the PTA. There were no questions that asked for the justification or rationale for the decision to include the spine in the curriculum. Many programs, over $80 \%$ of responding programs, reported they include grades IIV mobilizations didactically and in laboratory exercises. Additionally, programs reported utilizing a variety of teaching methods to convey the information to students which is consistent with the approach to teaching manipulation in PT programs (Boissonnault, Bryan \& Fox, 2004). The literature demonstrates that the lecture method continues to be the most prevalent teaching technique utilized in the college classroom and this current research supports that perspective (Lammers \& Murphy, 2002). However, it is also recognized in the literature that the lecture method is limited in developing critical thinking that can be applied in a clinical setting (Shreeve, 2008) Therefore, the movement towards utilizing more non-lecture methods for disseminating content in a classroom setting addresses this concern (Lammers \& Murphy, 2002).

The findings of this present study reflect that the respondents selected more than one choice including alternatives to lecture further support this movement towards activity-based learning. Activity-based learning is another representation of the application of behaviorist and constructivist theories in PTA curriculum. However, there was a limitation found within some of the formatting of these questions during the initial data collection phase. This limitation affected the ability of the respondents to select more than one response. There were four surveys 
completed during this initial time-period. This issue was quickly rectified within 24 hours of the survey being sent to programs and most likely did not skew results significantly.

PTA programs indicated that their clinical partner stakeholders utilize joint mobilizations in clinical practice and expect competency from their PTA students. This is supported by the results of the clinician practice survey of PTAs in 2010 revealing joint mobilizations are frequently used in the clinic (HumRRO, 2011). The inclusion of a skill that is determined to be valuable to clinical practice and is a task included in contemporary practice is in alignment with behaviorist framework (Doolittle \& Camp, 1999; Clark, Threeton, \& Ewing, 2010). Developing strategies that bridge the gap from the educational foundation to clinical practice can meet stakeholder requests. In an informal survey of PTA educators in 2014 by APTA's Director of PTA Services, the most common reasons given by the 165 respondents for why joint mobilizations were taught were: it was an expectation for clinical education (97 or 71.9\%); employers want PTAs to have the skill (61 or $45.2 \%)$ and faculty believe it is necessary to be a competent clinician (32 or 23.7\%). The findings from this current study support the findings of the informal survey that was referenced in an FSBPT Forum article (Berry \& McKnight, 2012). It would have been interesting to see if the clinical partner expectations were in alignment with State regulatory language. There were only 17 faculty members $(12.6 \%)$ that responded in the informal survey cited above that reported the reason they included joint mobilizations in their programs' curricula was because it is permitted by the State Practice Act.

The responses to the last few questions provided the respondents with the ability to express their opinions about the obvious discrepancies within the organizations that influence PT practice and education as well as the competency level of their students. Several programs indicated that they felt the students in a PTA program were adequately prepared to perform joint 
mobilizations. They also felt peripheral joint mobilizations should be an entry-level skill for PTAs and agreed that spinal mobilizations should not. A thought-provoking finding is that several programs felt the APTA documents regarding joint mobilizations should be in more alignment with CAPTE and FSBPT. This finding should inspire further discussions within these agencies to see if there is potential for change and growth. These conversations would most likely be initiated within the Education Section and/or PTA Caucus of the APTA. However, APTA policy change could only occur with a motion being presented to the APTA House of Delegates; the policy making group that meets annually.

The findings of this study highlight the discrepancies in the professional documents within Physical Therapy professional literature regarding the PTA performing joint mobilizations. The survey responses indicate that faculty are teaching joint mobilization theory and practical skills in PTA programs around the country despite the well documented position statement of the APTA. A number of State Practice Acts permit the PTA to provide the skill, several States provide specific language permitting the PTA to perform the skill (a direct contradiction to the APTA position) and still other States are intentionally vague which prevents contradicting the APTA. However, a limitation of this survey is it did not collect State specific data to examine if the responses are in direct conflict with individual States.

Within the last five years, CAPTE experienced a paradigm shift as a result of practice analysis surveys conducted by FSBPT. As a result, the teaching of the skill of joint mobilizations is not penalized by CAPTE during PTA program accreditation reviews and, furthermore, knowledge of joint mobilizations is assessed on the PTA national licensing examination. The majority of PTA educators surveyed in this current study believe that the statements from 
FSBPT, CAPTE and State practice acts should be more consistent, and ultimately, the skill of peripheral joint mobilization should be one that the PTA practices in States where permitted.

This study provides a picture to PTA educators of the perspectives of $46 \%$ colleagues within the academic setting regarding teaching the PTA joint mobilizations. Furthermore, this study outlines where and how joint mobilizations are presented to a PTA student within the curriculum, which techniques are highlighted, and teaching strategies employed in the classroom lecture and practice laboratory settings.

The current study has several strengths and provides a catalyst for future research to examine the strategies employed by programs for teaching and assessment of the skill of peripheral joint mobilizations. This knowledge could then lead to research to determine the effectiveness of these strategies within PTA curriculum. Respondents offered a variety of strategies mentioned within the survey regarding the instruction and assessment of PTA joint mobilization skills that were in alignment with those employed in PT programs (Boissonnault, Bryan \& Fox, 2004). In a survey of PTs regarding the decision-making process in choosing interventions, a common reason given was the intervention was taught in their entry-level education (Turner \& Whitfield, 1997). If evaluating PTs are choosing to include joint mobilizations as a component of a treatment plan that is potentially delegated to a PTA, this further supports the need to include joint mobilization education in the PTA curriculum. A comparison of the different instructional strategies would be appropriate for further research within the field of PTA education. This study also provides a strong foundation for future research to examine PTA curriculum and the effectiveness of teaching methods employed in PTA programs. 
This study also has some limitations that were present from the beginning and those that didn't present until the data collection process was terminated. This current study was not grounded in educational theory from the beginning. In a Physical Therapy perspective article published in 2016, it was suggested that PT education research grounded in in theoretical concepts would be important in improving the development of clinical reasoning skills (Jensen, Nordstrom, Segal, McCallum, Graham, \& Greenfield 2016). This limitation should provide a starting point for research that expands upon this current study regarding how educational theory influences PTA curriculum and the decision making within the process of curriculum design.

Limitations that presented themselves later in the process were a result of the response selections design where timeframes were involved. The " 0 " response should have been a separate choice instead of being included within a time frame, for example: " $0-4$ ". Including zero into a range may have affected some of the choices provided. Another limitation is the number of questions was restricted in the survey development. There were 33 questions within the survey with a recommend 15-20 minutes for completion time. The principle investigator was cognizant of how a significantly lengthy survey would affect participation. A self-imposed restriction of survey questions prevented the researcher from investigating program perceptions further. The inclusion of more questions or an interview follow-up for respondents may have provided more qualitative information that could have enriched the data.

The findings from this research demonstrate that PTA students are receiving a wide-range of joint mobilization learning experiences. This curriculum variability exists despite being influenced from the same CAPTE criteria and students taking the same national licensing examination. The disparity does not appear to be influenced by the APTA stance because the majority of programs surveyed include joint mobilizations within the curriculum. The variability 
within PTA programs combined with the jurisdictional inconsistency of the PTA in practice perpetuates the confusion regarding manual therapy delegation to the PTA. Curriculum variability was also a finding among PT programs in 2004 and highlighted a need for guidelines for those teaching joint mobilizations (Boissonnault, Bryan \& Fox, 2004). The findings discussed in this current research could be the catalyst in developing guidelines for PTA education. 


\section{References}

Adrian, L. (2010). Is It or Isn't It? A Systematic Approach to Scope of Practice Decisions. Federation Forum. Spring 2010. Retrieved from https://www.fsbpt.org/download/Forum_Spring2010_SystematicApproach.pdf

American Chiropractic Association. (2016). Practice Resources. Retrieved from https://www.acatoday.org/PracticeResources.

American Physical Therapy Association. (2000). Position Statement: Procedural Interventions Exclusively Performed by Physical Therapists. Retrieved from http://www.apta.org/uploadedFiles/APTAorg/About_Us/Policies/Practice/ProceduralInter ventions.pdf\#search=\%22interventions exclusively $\% 22$

American Physical Therapy Association. (2011). Today’s Physical Therapist: A Comprehensive Review of a $21^{\text {st }}$-Century Health Care Profession. Retrieved from: https://www.apta.org/uploadedFiles/APTAorg/Practice_and_Patient_Care/PR_and_Mark eting/Market to_Professionals/TodaysPhysicalTherapist.pdf

American Physical Therapy Association. (2012). Board of Directors' Guidelines: Defining Physical Therapy in State Practice Acts. Retrieved from http://www.apta.org/uploadedFiles/APTAorg/About_Us/Policies/Practice/DefiningPhysic alTherapyStatePracticeActs.pdf\#search $=\% 22$ state practice acts $\% 22$

American Physical Therapy Association. (2012). Minimum Skills of Physical Therapist Assistant Graduates at Entry Level. Retrieved from: http://www.apta.org/uploadedFiles/APTAorg/About_Us/Policies/Education/MinimumRe quiredSkillsPTAGrads.pdf\#search=\%22minimum skills\%22 
American Physical Therapy Association. (2013). Physical Therapists and Direction of Mobilization/Manipulation An Educational Resource Paper. Retrieved from https://www.apta.org/StateIssues/Manipulation/PTsDirectionofMobilizationManipulation/ American Physical Therapy Association. (2014). RC 20-12 Feasibility Study for Transitioning to an Entry-Level Baccalaureate Physical Therapist Assistant Degree; Supplemental Report to 2014 House of Delegates.

American Physical Therapy Association. (2015). Jurisdictional (Legal) Scope of Physical Therapist Practice. Retrieved from: http://www.apta.org/ScopeOfPractice/Jurisdictional/ American Physical Therapy Association. (2015). The Guide to Physical Therapist Practice. Retrieved from http://guidetoptpractice.apta.org/

American Physical Therapy Association. (2017). APTA Sections. Retrieved from: http://www.apta.org/Sections/

American Physical Therapy Association Center for Integrity in Practice. (2014). State Practice Acts. Retrieved from http://integrity.apta.org/UpholdingIntegrity/StatePracticeActs/ Ben-Sorek, S., Davis, C.M. (1988). Joint Mobilization Education and Clinical Use in the United States. Phys Ther.68(6), 1000-1004.

Berry, J. (2010). Interventions Performed by Physical Therapist Assistant Students During Clinical Education: A Nationwide Survey Regarding Consistency with APTA and CAPTE Positions. [PowerPoint slides].

Berry, J., McKnight, B. (2012). PTA Update: What are the Current Issues Relating to the PTA? Federation Forum. FSBPT Annual Meeting Fall 2012. 
Bockarie, A. (2002). The Potential of Vygotsky's Contributions to Our Understanding of Cognitive Apprenticeship as a Process of Development in Adult Vocational and Technical Education. The Journal of Career and Technical Education.19(1), 47-66.

Boissonnault, W., Bryan, J.M., Fox, K. (2004). Joint Manipulation Curricul in Physical Therapist Professional Degree Programs. J Orthop Sports Phys Ther. 34(4),171-182. doi: 10.2519/jospt.2004.34.4.171

Boissonnault, W., Bryan, J.M. (2005). Thrust Joint Manipulation Clinical Education Opportunities for Professional Degree Physical Therapy Students. J Orthop Sports Phys Ther. 35(7),416-423. doi: 10.2519/jospt.2005.35.7.416

Canoni, A., Canoni, E. (2017). Proceedings from APTA of MA PTA SIG Meeting: PT/PTA Scope of Practice and Improving the Clinical Relationship. Baystate College, Boston, MA.

Chaudry, A.N. (2014). Preventing the Legal Complaint in Physical Therapy: Strategies to Enhance Legally Competent Care for Best Practice. [PowerPoint Slides].

Clark, R.W., Threeton, M.D., Ewing, J.C. (2010). The Potential of Experiential Learning Models and Practices in Career and Technical Education \& Career and Technical Teacher Education. Journal of Career and Technical Education. 25(2).

Commission on Accreditation in Physical Therapy Education (2017). Aggregate Program Data. 2016-17 Physical Therapist Assistant Educational Programs Fact Sheets.

Commission on Accreditation in Physical Therapy Education (2017). What We Do. Retrieved from: http://www.capteonline.org/Home.aspx

Commission on Accreditation in Physical Therapy Education (2013). Evaluative Criteria PTA Programs. Retrieved from: 
http://www.capteonline.org/uploadedFiles/CAPTEorg/About_CAPTE/Resources/Accredi tation_Handbook/EvaluativeCriteria_PTA.pdf

Commission on Accreditation in Physical Therapy Education (2014). Evaluative Criteria PT Programs. Retrieved from: http://www.capteonline.org/uploadedFiles/CAPTEorg/About_CAPTE/Resources/Accredi tation_Handbook/EvaluativeCriteria_PT.pdf

Commonwealth of Massachusetts Board of Allied Health. (2017). 259 CMR 5.00 Physical Therapists. Retrieved from: http://www.mass.gov/ocabr/licensee/dplboards/ah/regulations/rules-and-regulations/259-cmr-500.html

Courtney, C.A., Steffen A.D., Fernandez de Las Peñas, C., Kim J., Chmell, S.J. (2016). Joint Mobilization Enhances Mechanisms of Conditioned Pain Modulation in Individuals with Osteoarthritis of the Knee. J Orthop Sports Phys Ther. 46(3):168-176.

doi: $10.2519 /$ jospt.2016.6259

Cuesta-Vargas, A.I., González-Sánchez, M., Lenfant, Y. (2015). Inertial Sensors as Real-Time Feedback Improve Learning Posterior-Anterior Thoracic Manipulation: A Randomized Controlled Trial. Journal of Manipulative and Physiological Therapeutics. 38(6), 425433. doi: 10.1016/j.jmpt.2015.04.004.

Descarreaux, M., Dugas, C., Lalanne, K., Vincelette, M., Normand, M.C. (2006). Learning Spinal Manipulation: the Importance of Augmented Feedback Relating to Various Kinetic Parameters. The Spine Journal. 6, 138-145. doi: 10.1016/j.spinee.2005.07.001

Deyle, G.D., Henderson, N.E., Matekel, R.L., Ryder, M.G. Garber, M.B., Allison, S.C. (2000). Effectiveness of Manual Physical Therapy and Exercise in Osteoarthritis of the Knee. Annals of Internal Medicine. 132:173-181. 
Deyle, G.D., Alison S.C., Matekel, R. L., Ryder, M.G., Stang, J.M., Gohdes, D.D., Hutton, J.P., Henderson, N.E., Garber, M.B. (2005). Physical Therapy Treatment Effectiveness for Osteoarthritis of the Knee: A Randomized Comparison of Supervised Clinical Exercise and Manual Therapy Procedures versus a Home Exercise Program. Physical Therapy. $85: 1301-1317$.

DiFabio, R.P. (1992). Efficacy of Manual Therapy. Physical Therapy. 72(12)

DiFabio, R.P. (1999). Manipulation of the Cervical Spine. Physical Therapy.79(1):50-65.

Doolittle, P.E., Camp, W.G. (1999). Constructivism: The Career and Technical Education Perspective. Journal of Career and Technical Education. 16(1).

Federation of State Boards of Physical Therapy. (2011). The Model Practice Act for Physical Therapy. $5^{\text {th }}$ ed. Retrieved from https://www.fsbpt.org/download/mpa_5thedition2011.pdf

Federation of State Boards of Physical Therapy. (2012). The History of FSBPT. Retrieved from: http://history.fsbpt.org/

Federation of State Boards of Physical Therapy. (2017). Sample Violations and Complaints. Retrieved from: https://www.fsbpt.org/ThePublic/FileaCompliant/SampleViolationsComplaints.aspx Flynn, T. W. (2002). Move It and Move On. JOSPT. 32:192-193.

Gonzalez-Sanchez, M., Ruiz-Mueoz, M., Avila-Bolivar, A.B., Cuesta-Vargas, A.I. (2016). Kinematic Real-Time Feedback is More Effective Thank Traditional Teaching Method in Learning Ankle Joint Mobilisation: A Randomised Controlled Trial. BMC Medical Education. 16.1 doi: http://dx.doi.org.prx-usa.lim.net/10.1186/s12909-016-0789-8. 
Gorgos, K.S., Wasylyk, N.T., Van Lunen, B.L., Hoch, M.C. (2014). Inter-clinician and Intraclinician Reliability of Force Application During Joint Mobilization: A Systematic Review. Manual Therapy. 19,90-96. doi: 10.1016/j.math.2013.12.003

Hayhurst, C. (2012). The Joint Manipulation Debate. PT in Motion. 4(11), 28-35. Retrieved from: http://www.apta.org/PTinMotion/2012/12/Feature/TheJointManipulationDebate/

Human Resources Research Organization. (2011). Analysis of Practice for the Physical Therapy Profession: Entry-Level Physical Therapist Assistants. Prepared for FSBPT. Retrieved from: http://www.fsbpt.org/Portals/0/documents/freeresources/PA2011_PTAFinalReport20111109.pdf

Jansen, M.J., Viechtbauer, W., Lenssen A.F., Hendriks, E.J.M., de Bie, R.A., (2011). Strength Training Alone, Exercise Therapy Alone, and Exercise Therapy with Passive Manual Mobilisation Each Reduce Pain and Disability in People with Knee Osteoarthritis: a Systematic Review. Journal of Physiotherapy. 57:11-20. doi: 10.1016/S18369553(11)70002-9.

Jensen, G.M., Norstrom, T., Segal, R.L., McCallum, C., Graham, C., Greenfield, B. (2016). Education Research in Physical Therapy: Visions of the Possible. Phys Ther. 96:18741884. doi: $10.2522 / p t j .20160159$

Jette, A.M., Delitto, A. (1997). Physical Therapy Treatment Choices for Musculoskeletal Impairments. Physical Therapy. 77(2):145-154.

Kaur, A.N., Sharma, A., Singh, A., Singh, J. (2014). Manipulation versus Mobilization for Spine: A Systemic Review. Indian Journal of Physiotherapy and Occupational Therapy. 18(1). Keating, J., Matyas, T.A., Bach, T.M. (1993). The Effect of Training on Physical Therapists' Ability to Apply Specified Forces of Palpation. Physical Therapy. 73(1). 
Kuwiboonsilp, W., Sakulsriprassert, P., Pichaiyongwongdee, S., Adisaiphaopan, R., Mingsoongnern, S. (2015). Immediate Effect of Muscle Energy Technique and Mobilization on External Rotation Angle in Individuals with Shoulder Adhesive Capsulitis. Indian Journal of Physiotherapy and Occupational Therapy. 9(2)220-226.

Lammers, W.J., Murphy, J.J. (2002). A Profile of Teaching Techniques Used in the University Classroom; A Descriptive Profile of a US Public University. Active Learning in Higher Education. 3(1):54-67.

Lee, M., Moseley, A., Refshauge, K. (1990). Effect of Feedback on Learning a Vertebral Joint Mobilization Skill. Physical Therapy.70(2).

Lee, T.D., Swanson, L.R., Hall, A.L. (1991). What is Repeated in a Repetition? Effects of Practice Conditions on Motor Skill Acquisition. Physical Therapy. 71(2)

Lonnemann, E. (2013). Thoughts on the partial delegation of joint manipulation. The Journal of Manual \& Manipulative Therapy, 21(2), 67-70. doi: 10.1179/1066981713Z.00000000056.

Manipulation Education Committee, APTA Manipulation Task Force. (2004). Manipulation Education Manual for Physical Therapist Professional Degree Programs. Retrieved from https://www.apta.org/uploadedFiles/APTAorg/Educators/Curriculum_Resources/APTA/ Manipulation/ManipulationEducationManual.pdf

Mohr, T., Ingram, D., Mabey, R., Walker, J.R. (2014). Ten Year History of Physical Therapist Assistant Disciplinary Reports. [Supplemental Material] HPA PTJ-PAL. J1-J15.

Nicholson, G.G. (1985). The Effects of Passive Joint Mobilization on Pain and Hypomobility Associated with Adhesive Capsulitis of the Shoulder. Journal of Orthopedic and Sports Physical Therapy. 6(4) 238-246. 
Plack, M.M., Williams, S., Miller, D., Malik, F., Sniffen, J., McKenna, R., Gilner, G. (2006). Collaboration Between Physical Therapists and Physical Therapist Assistants: Fostering the Development of the Preferred Relationship Within a Classroom Setting. Journal of Physical Therapy Education. 20(1), 3-14.

Portney, L.G., Watkins, M.P. (2000). Foundations of Clinical Research Applications to Practice. Upper Saddle River, New Jersey: Prentice Hall Health.

Pringle, R.K. (2004). Guidance Hypothesis with Verbal Feedback in Learning a Palpation Skill. Journal of Manipulative and Physiological Therapeutics. 27(1),36-42. doi: 10.1016/j.jmpt.2003.11.004

Razek, R.A., Shenouda, M.M. (2014). Efficacy of Mulligan's Mobilization with Movement on Pain, Disability, and Range of Motion in Patients with Knee Osteoarthritis: A Randomized Controlled Pilot Study. Indian Journal of Physiotherapy and Occupational Therapy. (8)1, 242-248.

Scaringe, J.G., Chen, D., Ross, D. (2002). The Effects of Augmented Sensory Feedback Precision on the Acquisition and Retention of a Simulated Chiropractic Task. Journal of Manipulative and Physiological Therapeutics. 25(1)34-41.

Scott, J., Sarkees-Wircenski, M. (2008). Overview of Career and Technical Education $4^{\text {th }}$ ed. Homewood, Il: American Technical Publishers.

Sharma, N.K., Sabus, C.H. (2012).Description of Physical Therapist Student Use of Manipulation During Clinical Internships. Journal of Physical Therapy Education. 26(2), 9-18. 
Shreeve, M.W. (2008). Beyond the Didactic Classroom: Educational Models to Encourage Active Student Involvement in Learning. The Journal of Chiropractic Education. 22(1):23-28.

Sizer, P.S., Felstehausen, V., Sawyer, S., Dornier, L., Matthews, P., Cook, C. (2007). Eight Critical Skill Sets Required for Manual Therapy Competency: A Delphi Study and Factor Analysis of Physical Therapy Educators of Manual Therapy. Journal of Allied Health, 36(1), 30-40.

Snodgrass, S.J., Rivett, D.A., Robertson, V.J. (2006). Manual Forces Applied During Posteriorto-Anterior Spinal Mobilization: A Review of the Evidence. Journal of Manipulative and Physiological Therapeutics.29(4),316-329. doi: 10.1016/j.jmpt.2006.03.006

Solon, M.K. (2013). Curriculum Design in Physical Therapist Education. Faculty Development Workshop. University of Indianapolis May 18,2013

Struessel, T.S., Carpenter, K.J., May, J.R., Weitzenkamp, D.A., Sampey, E., Mintken, P.E. (2012). Student Perception of Applying Joint Manipulation Skills During Physical Therapist Clinical Education: Identification of Barriers. Journal of Physical Therapy Education. 26(2),19-29.

Threlkeld A.J. (1992). The Effects of Manual Therapy on Connective Tissue. Physical Therapy. $72(12)$

Triano, J.J., Rogers, C.M., Combs, S., Potts, D., Sorrels, K. (2002). Developing Skilled Performance of Lumbar Spine Manipulation. Journal of Manipulative and Physiological Therapeutics. 25(6), 353-361.

Triano, J.J., Rogers, C.M., Combs, S., Potts, D., Sorrels, K. (2003). Quantitative Feedback Versus Standard Training for Cervical and Thoracic Manipulation. Journal of 
Manipulative and Physiological Therapeutics. 26(3),131-138. doi:10.1016/S0161$4754(02) 54105-1$

Triano, J.J., Bougie, J., Rogers, C., Scaringe ,J., Sorrels, K., Skogsbergh, D, Mior, S. (2004). Procedural Skills in Spinal Manipulation: Do Prerequisites Matter? The Spine Journal. 4,557-563. doi: 10.1016/j.spinee.2004.01.017

Triano, J.J., Scaringe, J., Bougie, J., Rogers, C. (2006). Effects of Visual Feedback on Manipulation Performance and Patient Ratings. Journal of Manipulative and Physiological Therapeutics.29(5),378-385. doi: 10.1016/j.jmpt.2006.04.014

Triano, J.J., McGregor, M., Dinulos, M., Tran, S. (2014). Staging the Use of Teaching Aids in the Development of Manipulation Skill. Manual Therapy. 19,184-189. doi: 10.1016/j.math.2014.01.003

Turner, P., Whitfield, T.W. (1997). Physiotherapists' Use of Evidence Based Practice: A CrossNational Study. Physiother Res Int. 2:17-29.

Vermeulen, H.M., Obermann, W.R., Burger, B.J., Kok, G.J., Rozing, P.M. \& van den Ende, C.H.M. (2000). End Range Mobilization Techniques in Adhesive Capsulitis of the Shoulder Joint: A Multiple Subject Case Report. Physical Therapy. 80:1204-1213. Qualtrics ${ }^{\circledR}$. (2017). Qualtrics ${ }^{\circledR}$ Web-Based Survey Platform. Retrieved from: https://www.qualtrics.com/

Watson, T.A., Radwan, H. (2001). Comparison of Three Teaching Methods for Learning Spinal Manipulation Skill: A Pilot Study. The Journal of Manual \& Manipulative Therapy. 9(1), 48-52.

Winstein, C.J. (1991). Knowledge of Results and Motor Learning - Implications for Physical Therapy. Physl Ther. 71(2) 
Wulf, G., Shea, C.H., Matschiner, S. (1998). Frequent Feedback Enhances Complex Motor Skill Learning. Journal of Motor Behavior. 30(2)

Yang, J., Chang, C., Chen, S., Wang, S., Lin, J. (2007). Mobilization Techniques in Subjects with Frozen Shoulder Syndrome: Randomized Multiple-Treatment Trial. Phys Ther. 87(10):1307-1315. doi: 10.2522/ptj.20060295

Zemadanis, K., Sykaras, E., Athanasopoulos, S., Mandalidis, D. (2015). Mobilization with Movement Prior to Exercise Provides Early Pain and Functionality Improvements in Patients with Patellofemoral Pain Syndrome. International Musculoskeletal Medicine. 37(3), 101-108 


\section{Appendix A - Recruitment Email}

My name is Renae Gorman and I am a Doctorate of Education candidate with the University of St. Augustine and an Assistant Professor at Springfield Technical Community College in the PTA program. I am contacting all PTA program directors and/or instructors of PTA joint mobilization content to seek information regarding the instruction of joint mobilization within the PTA curriculum. I would appreciate it if the person primarily responsible for teaching the joint mobilization content be the individual that completes the survey. The intent of the survey is to determine how PTA programs are teaching and assessing the manual therapy skill of joint mobilizations. This survey is the preliminary step to future research in the techniques used to teach and assess as well as the development of new strategies for teaching joint mobilizations.

The survey consists of 32 questions and should take 30 minutes to complete. I would greatly appreciate your participation. Completion of the survey will serve as informed consent for the utilization of your responses. The survey can be found at the following Qualtrics link (insert link here). Information and responses will be kept confidential and anonymous with no identifying information included in the study. Results will be stored on a Qualtrics secured server with the primary investigator being the only individual with access to the files. All information obtained in this study is strictly confidential unless disclosure is required by law.

Thank you again for consideration of participation in this survey research. If you would like to see the results of this study or have any other questions, I can be reached at rgorman@stcc.edu.

Cordially,

Renae Gorman PT, DPT, MTC, OCS 


\title{
Appendix B
}

\section{University of St. Augustine for Health Sciences}

\author{
IRB \# PT 0810-241 \\ Out of town: 800-241-1027 x1234; Local: (904) 826-0084 x1234
}

Full Review __ Expedited Review $\underline{X X}$

Project Title: Teaching Joint Mobilizations in Physical Therapist Assistant Programs: Implications for Instruction and Policy

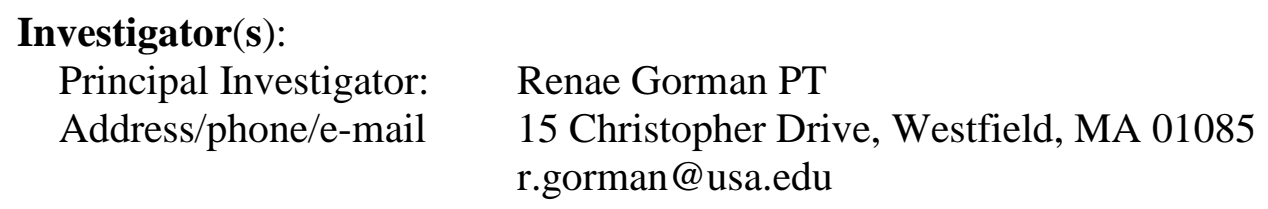

Co-Investigator(s) - (If Appropriate):

Address/phone/e-mail

Consider:

* Student Research

\begin{abstract}
:
This research seeks to answer the question: Are physical therapist assistant programs teaching the manual therapy skill of joint mobilizations? This study also seeks to gather information regarding how the techniques are being instructed and assessed within the PTA programs. This information will be the foundation for future research regarding developing instructional and evaluation strategies for manual therapy skills. The findings of this study may also affect the professional utilization of the physical therapist assistant in clinical use of manual therapy. Findings of this study are expected to identify the differing perspectives in clinical practice of manual therapy by physical therapist assistants. The findings are pertinent due to conflicting statements by the professional organizations and the accreditor of physical therapist assistant educational programs.
\end{abstract}

Significance and Specific Aims: This research could identify the need for all of the organizations involved in physical therapist assistant education to be in alignment. This could potentially lead to policy change regarding the utilization of the physical therapist assistant in practice and may eventually support the need to advance the entry-level degree of the assistant to a Bachelor's Degree.

Funding Source (if externally funded): None

Research Plan: Develop a survey to send to PTA education Program Directors asking for the information regarding if and how the skill of joint mobilizations is taught. A list of PTA education programs will be acquired from on the Commission on Accreditation of Physical Therapy Education (CAPTE) website. An email cover letter with the link to the Qualtrics survey 
will be sent to each PTA program director with the request the letter be forwarded to the individual primarily responsible for teaching joint mobilization content. The completion of the survey will serve as informed consent.

Approval from The Facility Where the Research Is To Be Conducted (if applicable): IRB at Springfield Technical Community College \& University of St. Augustine for Health Sciences

Potential Health Benefits: None

Potential Financial Benefits: None

Potential Health Risks: None

Potential Financial Risks: None

Conflict of Interest: None

Other State Requirements:
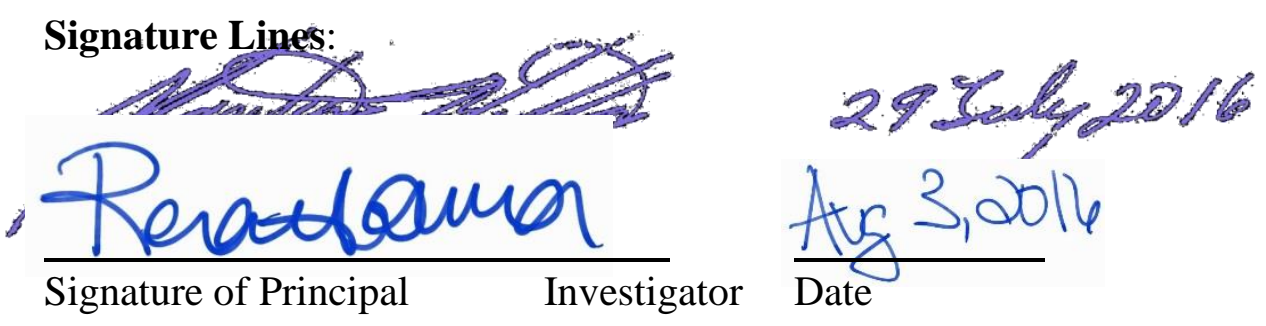

Signature of

Advisor

Date

Faculty Advisor confirmation:

I have read this submission and it meets the requirements established by the University of St. Augustine for Health Sciences Institutional Review Board.

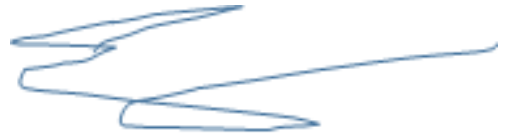

Faculty Research Advisor's Signature

Please check: This is a(n): Initial Submission $X$ / Resubmission 


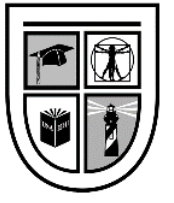

\section{University of St. Augustine}

\section{$\begin{array}{lllllllllllllllll}F & O & R & H & E & A & L & T & H & S & C & \text { I } & E & N & C & E & S\end{array}$}

1 UniVERSity BouleVARD - ST. Augustine, FL 32086-5783 - (904) 826-0084 - FAX (904) 826-0085 -WeBsite: www.usa.edu

October 26, 2016

Renae H. Gorman

15 Christopher Drive

Westfield MA 01085

RE: PT-0810-241 "Are Physical Therapist Assistant Programs Teaching Joint Mobilizations? Implications for Instruction and Policy"

Dear Ms. Gorman,

A member of the Institutional Review Board (IRB), responsible for the review of research involving human subjects, reviewed your original proposal, noted the revisions provided by you upon their request and approved the revised project referenced above. Approval for the project will be for one year, starting October 26, 2016.

If a University of St. Augustine For Health Sciences faculty member or student leaves the University prior to completion of a USAHS IRB-approved study, the study may be continued until expiration of that IRB approval. The IRB approval will expire on October 26, 2017.

This approval is granted with the understanding that no changes may be made in the procedures to be followed, nor in the consent form(s) to be used, until after such modifications have been submitted to the IRB for review and approval. Please be sure your consent form includes the IRB contact name and telephone number (Dr. Lisa Chase, Chair, University of St. Augustine for Health Sciences Institutional Review Board, 904-826-0084 x1234, Ichase@usa.edu). Researchers must retain a copy of the signed consent form in their files for three years following completion of the project and must provide a copy of the consent form to the subject(s).

Any unanticipated problems involving risks to human subjects or serious adverse effects must be promptly reported to the IRB.

Prior to the expiration of this approval, you will receive notification of the need for updated information to be used for the project's continuing review. When project is completed, please notify the IRB in writing. Thank you.

Sincerely, Lisa A. Chase, PhD, PT

Chair, IRB

Cc: M. Miller

C. Redwing 
Springfield Technical Community College IRB

\begin{tabular}{l|l|l}
10 & 27 & 16 \\
\hline Date Submitted
\end{tabular}

Springfield Technical Community College

Institutional Review Board

Exempt Protocol Summary Form

Are Physical Therapist Assistant Programs Teaching Joint Mobilizations? Implications for Instruction and Policy

Title of Research Project

Renae H. Gorman

rgoman@stcc.edu

\begin{tabular}{llll}
\hline Principal Investigator/Project Director & Department Phone & Extension & Email address \\
\hline Co-investigator/Student Investigator & Department Phone & Extension & Email address \\
& & & \\
\hline Co-investigator/Student lnvestigator & Department Phone & Extension & Email address \\
\cline { 2 - 4 } Anticipated Funding Source: & Self-funded & & \\
\cline { 2 - 4 } & &
\end{tabular}

Projected Duration of Research:

$$
\text { Nov. } 2016 \text { - Jan. } 2017
$$
Projected Starting Date:

Nov. 1, 2016

Other organizations and/or agencies, if any, involved in the study.

Research is being conducted in partial fulfillment of the requirements for the Doctorate of Education degree at the University of St. Augustine

Exempt under code (see definitions on page one-check one) $\quad 1 \quad X \quad 2 \quad \square \square 4 \square 5 \square 6$

SUMMARY ABSTRACT: Please supply a short description of project including a description of exactly how and what date will be collected. Please also include if relevant: Brief description of the participants, the location(s) of the project, data collection procedures, and procedure for maintain confidentiality of the data. If applicable, please attach a copy of the Informed Consent Form and/or the measures (questionnaires) to be used in the project.

\section{RESPONSIBILITIES OF THE PRINCIPAL INVESTIGATOR:}

- Any additions or changes in procedures in the protocol will be submitted to the IRB for written approval prior to these changes being implemented

- Any problems connected with the use of human subjects once the project has begun must be communicated to the IRB Chair

- The principal investigator is responsible for retaining informed consent documents for a period of three years after the project.

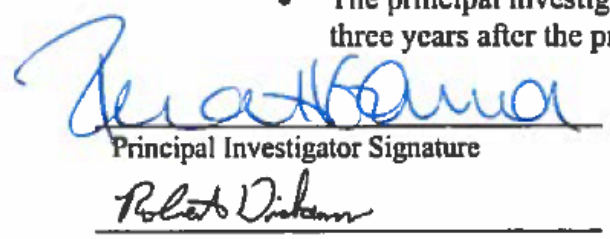

Signature of IRB Committce Chair

IRB Chair: Check 1 box

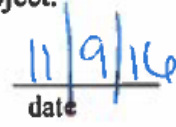

$11 / 4 / 16$
Co-Investigator/Student Signature (if appropriate)

datc

$\mathrm{X}$ Approved

Approved with conditions

Refer to full committee review 


\section{Appendix C - Survey}

(Format modified for online distribution)

Survey Questions:

1. I understand the intent of the survey and give my consent to participate
a. Yes
b. No

2. As a faculty member of the PTA program, what is your primary role
a. Program Director
b. Director of Clinical Education
c. Faculty
d. Adjunct faculty
e. Other:

3. In what region of the country is your program located?
a. Northeast
b. Southeast
c. Midwest
d. Southwest
e. Northwest

4. What type of institution is your program housed in?
a. Public
b. Private
c. Other:

5. Do you hold any advanced manual therapy certifications?
a. Yes (please list: )
b. No

6. Do you have any patient contact hours?
a. Yes
b. No. If no, skip to question \#

7. If yes, in what setting do you practice?
a. Hospital-based outpatient
b. Private practice
c. Acute care setting
d. SNF setting
e. Home Care setting
f. Other: (Please specify) 
8. If yes, how many hours a week are associated with direct patient care?
a. 0-5 hours/week
b. 6-15 hours/week
c. 16-24 hours/week
d. 25 hours or more/week

9. Are you an APTA member?
a. Yes
b. No, please go to question \#

10. IF an APTA member, do you belong to any sections?
a. Yes, please list:
b. No

11. In the last 5 years, have you attended any APTA sponsored conferences (CSM, NEXT, state chapter)?
a. Yes, please list:
b. No

12. Do you hold memberships in any other organizations?
a. Yes, please list: (AAOMPT, )
b. No

13. Does your state practice act have any specific language regarding the PTA and joint mobilizations?
a. Yes, according to our state practice act, PTAs can NOT perform joint mobs
b. Yes, according to our state practice act, PTAs are allowed to perform joint mobs
c. No, there is no specific language that I am aware of in the practice act regarding the PTA and joint mobs
d. Don't know
e. Other

14. Do you require student APTA membership within your program?
a. Yes
b. No

15. Are you responsible for teaching manual therapy (Definition of manual therapy- maybe have in cover letter) in the curriculum?
a. Yes
b. No 
16. What courses do you require in your program prior to introducing manual therapy in your curriculum?
a. A \& P
b. Kinesiology
c. Other:

17. Of the following regions, which are included in the manual therapy component of the curriculum? (please mark all that apply)
a. Pelvis/Sacroiliac Joints
b. Lumbar Spine
c. Thoracic Spine
d. Cervical Spine
e. Upper Extremity Joints
f. Lower Extremity Joints

18. Regarding the joint mobilization content in your curriculum, where is it first presented?

a. Not at all
b. First semester
c. Second semester
d. Third semester
e. Fourth semester

The next set of questions is specifically about joint mobilizations of the periphery (Upper and Lower extremity joint mobilizations) If you do not include peripheral joint mobilizations within your curriculum, please go to question \#

19. How long has peripheral joint mobilizations been included in your program's curriculum?
a. 0-2 years
b. $3-5$ years
c. 6-10 years
d. 11-15 years
e. $>15$ years

20. Are peripheral joint mobilizations taught as a (mark all that apply)
a. Separate, required course
b. Subunit of another course: please list course (Orthopedics, therapeutic exercise, interventions)
c. Elective course
d. Other: 
21. Which technique(s) is(are) emphasized? Please mark all that apply
a. Paris
b. Cyriax
c. Kaltenborn
d. Maitland
e. Other: (Mennell, McKenzie, Grimsby, Mulligan, etc) Please list:

22. What mobilization grades do you teach didactically? Please mark all that apply
a. Grade I
b. Grade II
c. Grade III
d. Grade IV
e. Grade V
f. Other

23. What mobilization grades do you teach in a laboratory setting for clinical application? Please mark all that apply
a. Grade I
b. Grade II
c. Grade III
d. Grade IV
e. Grade V
f. Other

24. What teaching methods do you use when teaching joint mobilizations? (Please mark all that apply)
a. Demonstration
b. Lecture
c. Video
d. Simulation Lab
e. Required reading (texts, journals)
f. Other:

25. How many total hours are allotted to teaching joint mobilizations? Please include total of all teaching methods.
a. 0-2 hours
b. 2.5-4 hours
c. 4.5-6 hours
d. 6.5-10 hours
e. >10 hours 
26. How is the learning of joint mobilizations assessed?
a. Practical examination
b. Written examination
c. Practical and Written examination
d. Other

27. Do your clinical education partners expect your students to demonstrate competence regarding peripheral joint mobilizations at the time of clinical placements?
a. Yes
b. No

28. Do your clinical education partners expect your students to demonstrate competence regarding spinal joint mobilizations at the time of clinical placements?
a. Yes
b. No

29. What percentage of your clinical partners utilize joint mobilizations into practice?
a. $0-20 \%$
b. $21-40 \%$
c. $41-60 \%$
d. $61-80 \%$
e. $81-100 \%$
f. Don't know

For the following 3 questions, please choose the answer that is most in alignment with your professional beliefs

30. Does your program adequately prepare students to perform peripheral joint mobilizations during their clinical experiences?
a. Strongly agree
b. Agree
c. Neutral
d. Disagree
e. Strongly disagree

31. Peripheral joint mobilizations should be an entry-level skill for the PTA
a. Strongly Agree
b. Agree
c. Neutral
d. Disagree
e. Strongly disagree 
32. Spinal joint mobilizations should be an entry-level skill for the PTA
a. Strongly Agree
b. Agree
c. Neutral
d. Disagree
e. Strongly disagree

33. The language regarding the PTA and joint mobilization in documents from the APTA (PTA is NEVER the appropriate provider of peripheral or spinal joint mobilizations) should be in more alignment with the findings from CAPTE (no longer penalize programs for teaching peripheral joint mobilizations in PTA programs) and FSBPT (over half of PTAs are performing joint mobilizations in practice)
a. Strongly Agree
b. Agree
c. Neutral
d. Disagree
e. Strongly disagree

If you think there is other content that would be relevant to this research that is not included in this survey, please consider writing it in the space provided:

Thank you for your time and cooperation in completing this survey. Please submit your survey by the deadline of November 1, 2016. If you are interested in the results of this study, the primary researcher can be reached at rgorman@stcc.edu

If you would like information regarding the results of this research, please put your information in the space provided, 


\section{Appendix D}

APTA involvement: special interest group membership, advanced certifications, APTA conferences attended; Other professional organization membership

\begin{tabular}{|c|c|c|}
\hline $\begin{array}{l}\text { List of sections that respondents belong to } \\
\text { (in alphabetical order) } \\
\text { Many respondents belonged to more than one } \\
\text { section }\end{array}$ & $\begin{array}{l}\text { Acute } \\
\text { Aquatics } \\
\text { Cardio/Pulm } \\
\text { Electro/Wound } \\
\text { Education } \\
\text { Federal } \\
\text { Geriatrics } \\
\text { Hand \& UE } \\
\text { Health Policy \& Admin } \\
\text { Home Health } \\
\text { Neurology } \\
\text { Oncology } \\
\text { Orthopedics } \\
\text { Pediatrics } \\
\text { Private Practice } \\
\text { Research } \\
\text { Sports } \\
\text { Women's Health }\end{array}$ & $\begin{array}{l}2 \\
1 \\
1 \\
1 \\
87 \\
1 \\
8 \\
0 \\
3 \\
2 \\
10 \\
1 \\
33 \\
5 \\
1 \\
3 \\
5 \\
4 \\
\end{array}$ \\
\hline Certifications held & $\begin{array}{l}\text { Manual therapy certification (Paris) } \\
\text { Myofascial release certification } \\
\text { Functional Manual Therapy } \\
\text { Certification } \\
\text { Manual therapy institute } \\
\text { certification } \\
\text { Cranio-facial certification } \\
\text { Orthopedic Clinical Specialist } \\
\text { Certified Orthopedic Manual } \\
\text { Therapist (Maitland) } \\
\text { Fellow in the American Academy } \\
\text { of Orthopedic Manual Physical } \\
\text { Therapy } \\
\text { North American Institute of } \\
\text { Orthopedic Manual Therapy }\end{array}$ & $\begin{array}{l}1 \\
1 \\
1 \\
1 \\
1 \\
1 \\
1 \\
2\end{array}$ \\
\hline
\end{tabular}




\begin{tabular}{|l|l|l|}
\hline Conferences attended & Combined Sections & 59 \\
& Educational Leadership Conference & 18 \\
& NEXT & 24 \\
& Annual Chapter Meeting & 9 \\
& New Faculty Seminar & 1 \\
& Orthopedic Section Annual & 1 \\
& Meeting & \\
& CI Credentialing & 1 \\
& Student Conclave & 1 \\
& EXPO & 1 \\
\hline Other Memberships Listed & American College of Sports & \\
& Medicine & \\
& National Strength and Conditioning & \\
& Association & \\
& Council on Undergraduate & \\
& Research & \\
& Performing Arts Medicine & \\
& Association & \\
& National Athletic Trainers & \\
& Association & \\
& Intercollegiate Academic Clinical & \\
& Coordinators Council & \\
& American Board of Quality & \\
& Assurance and Utilization Review & \\
& Texas Community College & \\
& Teachers Assocation & \\
& American Academy of Orthopedic & \\
& Manual Physical therapists & \\
&
\end{tabular}




\title{
Appendix E
}

"Other" practice settings indicated by respondents

\author{
Community outreach \\ Free clinic \\ Long-term acute care \\ Multiple settings \\ Adult developmental disabilities \\ In-patient rehab \\ University athletes \\ Sports Medicine \\ Campus clinic \\ Various pediatric locations
}




\section{Appendix F}

\section{Prerequisite courses listed as "Other"}

Clinical Education I
Exercise Physiology
Functional and Applied Anatomy
Fundamentals of Treatment
Habilitation/Rehabilitation
Introduction to PT
Measurements and Procedures
Medical and Surgical Conditions
Modalities
Musculoskeletal Assessment
Musculoskeletal PT Interventions
Musculoskeletal Rehabilitation
Orthopedics
Pathology
Pathophysiology
Patient Care Skills
Physics
Professional Issues
Therapeutic Exercise




\section{Appendix G}

Courses indicated by respondents where joint mobilization information is included as a sub-unit

Orthopedics

Therapeutic Exercise

Interventions

Musculoskeletal

Clinical Anatomy \& Kinesiology

Clinical Rehabilitation

Practice Issues

Advanced Patient Care 


\section{Appendix H}

Joint mobilization techniques that were indicated in "Other"

\begin{tabular}{|l|}
\hline McKenzie \\
Mulligan \\
Grimsby \\
Mix of all \\
General \\
Osteopathic approach \\
Mennell \\
Muscle energy techniques \\
\hline
\end{tabular}




\section{Appendix I}

\section{Comments provided by participants in response to the final question of the survey}

- 'I've heard many PTs believe that patients can be taught some self-mobilizations or that can caregivers can be taught basic mobilizations. This seems rather odd as those same PTs in my experience also believe that PTAs are unqualified to perform joint mobilizations. Is there any research on self-mobs?"

- "I do believe that PTA students should, through the PTA practice act (APTA) be allowed to perform joint mobilizations in my state. If we are all about patient-centered PT, then why take this huge beneficial tool away from the ability of a PTA to provide their patients with this intervention to improve patient outcomes; PTAs are capable, they are being required to know this information and best learning practices involves knowledge and practical experience (best learned through hands-on approach)."

- "Our program receives compliments from clinical instructors regarding the preparation of our PTA students performing peripheral joint mobilization."

- "I believe joint mobilization should be taught as an entry-level skill for Grades I and II. Beyond that, the PTAs should have advanced training"

- "Mobilization techniques are on the NPTE for PTA"

- "We also teach some soft tissue mobilizations, some limited sub-occipital releases, and demonstrate limited SI muscle energy techniques."

- "Surveys that provide anonymous responses regarding PTAs who practice in states where peripheral joint mobilizations are denied... How many PTAs are actually performing peripheral joint mobilizations?"

- "If the PTA entry-level degree was increased to a BS level, leaving more time for teaching competency, I would definitely teach it. I also do not think that many students with limited prior patient handling skills should be told they are competent in providing joint mobilization. That goes for DPT students as well. I do not think that the anatomical and biomechanical preparation of the PTA is adequate to understand and provide spinal mobilization. Again this could be provided in a BS program. Our outpatient clinical instructors teach the students how they want it performed."

- "Due to NPTE questions regarding mobilization it is necessary to prepare students didactically, but since state law prohibits performance, we do not assess competency. We must prepare students to work in all states, however, so it is hard to continuing providing education without competency."

- "Number of years of clinical experience and continuing education completed by instructor."

- "Patient outcomes from joint mobilizations provided by a PT vs. a PTA."

- "Even though the clinician would like the PTA student to be competent in joint mobs, we explain to the CI the whole state practice act/APTA/CAPTE brouhaha. If the CI wants to teach and assess for competency, we say go for it!"

- "We teach joint mobilization in lab and lecture and allow students to practice on classmates. We do NOT expect competence in the clinic and instruct our students this is not an entry-level skill and should be acquired post-graduation. We assess knowledge of joint mobs with written exam only (not a skill exam) to prepare students for NPTE. We were penalized by CAPTE for teaching joint mobs to competence and were required to remove teaching to clinical competence from the program curriculum. Since the APTA has not yet changed its position statement on 
PTA performing joint mobs, and since I am an APTA member and very involved, I would like the APTA to change its position statement in regard to a PTA performing joint mobilizations before I revise the PTA curriculum to again include joint mobs to competence. At this time, the feedback from employers is although they would like PTA students to exhibit skill in joint mobs, they understand that this skill will be the responsibility of the employer after graduation and hire."

- "The last several questions, asking me to answer whether I agree or disagree with certain questions, are too vague. For instance, one question asked if peripheral joint mobilization should be an entry-level skill for the PTA. This is not an agree or disagree question. Do I believe they should have skill for a grade I or II to gate pain-yes, should they have an entry level skill for higher grades-no, not necessarily. And, it would depend on who is teaching these skills. Also, when asked if we adequately prepare students for clinical practice regarding mobilization, again too vague of a question. We provide them with expert instruction, including all contraindications, indications and legal ramifications, however, as per CAPTE, we do not hold them responsible for competency in these skills. Limiting PTAs in mobilization techniques is not consistent with other skills we are teaching them. For example, if we teach them how to perform a contract-relax technique to the hip flexors are they not also performing a muscle energy technique to influence mobilization of the innominate bone? Therefore, the questions here need to be more precise. We focus on soft tissue mobilization for our manual therapy. We agree that PTAs should not be performing joint mobilizations."

- "Defining mobilization vs passive ROM i.e.: patellar glides, scapular mobs."

- "My responses reflect that we do not teach to competence because of our state practice act only. Prior to our practice act change, peripheral mobs were taught to competence in our program."

- "For question \#31, I would answer Agree for Grade I and II for the time we are given, Grades III and IV if more time in curriculum."

- "I agree that the language should match what is actually going on in practice. Unfortunately, this is an area where PTAs are only receiving on the job training and then expected to master the skill."

- "CAPTE does not allow requiring the student to be a member of the APTA."

- "The fact that in attempting to simply increase passive ROM grades I and II are vitally important and probably practiced without actually saying you perform them."

- "The reason I do not believe that peripheral mobs should be an entry-level skill for PTAs is because of the curricular time constraints on PTA programs. We only have time to adequately introduce the concept but mastery would need to be completed in the clinic under and instructor with time and repetition, etc."

- "Requirement to understand and apply joint mobilization when stretching which is already included in PTA requirements."

- "It is naïve or ignorant to believe that PTAs are not primary providers of grade I-IV peripheral mobilizations. (But this appears to be the position of many in the APTA and CAPTE.) PTA programs need to be given the authority to teach these skills to competency instead of teaching to knowledge."

- "No, this is wonderful. APTA/CAPTE/FSBPT need to have an agreement or turn it over to state/Edu with open statement."

- "Note state to state there are huge differences in what clinicians expect a student to know." 